\title{
It Is a Balancing Act: The Interface of Scientific Evidence and Policy in Support of Effective Marine Environmental Management
}

Jemma-Anne Lonsdale ${ }^{1, *,+} \mathbb{D}$, Andrew B. Gill ${ }^{1,+}$, Khatija Alliji ${ }^{2}$, Silvana N. R. Birchenough ${ }^{1}$, Sylvia Blake ${ }^{1}$, Holly Buckley ${ }^{1}$, Charlotte Clarke ${ }^{1}$, Stacey Clarke ${ }^{3}{ }^{D}$, Nathan Edmonds ${ }^{3}$, Leila Fonseca ${ }^{1}$, Freya Goodsir ${ }^{1}$, Andrew Griffith ${ }^{1}$, Adrian Judd ${ }^{1}$, Rachel Mulholland ${ }^{1}$, Joe Perry ${ }^{1}$, Karema Randall ${ }^{1}$ and Daniel Wood ${ }^{1}$

1 Centre for Environment, Fisheries and Aquaculture Science, Pakefield Road, Lowestoft NR33 0HT, UK; Andrew.gill@cefas.co.uk (A.B.G.); silvana.birchenough@cefas.co.uk (S.N.R.B.); sylvia.blake@cefas.co.uk (S.B.); holly.buckley@cefas.co.uk (H.B.); charlotte.clarke@cefas.co.uk (C.C.); leila.fonseca@cefas.co.uk (L.F.); Freya.goodsir@cefas.co.uk (F.G.); andrew.griffith@cefas.co.uk (A.G.); adrian.judd@cefas.co.uk (A.J.); rachel.mulholland@cefas.co.uk (R.M.); joe.perry@cefas.co.uk (J.P.); Karema.randall@cefas.co.uk (K.R.); Daniel.wood@cefas.co.uk (D.W.)

2 MarineSpace, 8 Thorpe Road, Norwich NR1 1RY, UK; khatija.alliji@otmail.com

3 The Department for Environment, Food and Rural Affairs, Nobel House, 17 Smith Square, London SW1P 3JR, UK; Stacey.clarke@defra.gov.uk (S.C.); nathan.edmonds@defra.gov.uk (N.E.)

* Correspondence: jemma.lonsdale@cefas.co.uk

+ Both authors are first authors.

Citation: Lonsdale, J.-A.; Gill, A.B.; Alliji, K.; Birchenough, S.N.R.; Blake, S.; Buckley, H.; Clarke, C.; Clarke, S.; Edmonds, N.; Fonseca, L.; et al. It Is a Balancing Act: The Interface of Scientific Evidence and Policy in Support of Effective Marine Environmental Management. Sustainability 2022, 14, 1650. https:// doi.org/10.3390/su14031650

Academic Editor: Just

Tomàs Bayle-Sempere

Received: 13 December 2021

Accepted: 28 January 2022

Published: 31 January 2022

Publisher's Note: MDPI stays neutral with regard to jurisdictional claims in published maps and institutional affiliations.

Copyright: (C) 2022 by the authors. Licensee MDPI, Basel, Switzerland. This article is an open access article distributed under the terms and conditions of the Creative Commons Attribution (CC BY) license (https:// creativecommons.org/licenses/by/ $4.0 /)$.

\begin{abstract}
The marine environment is a complex system, and with growing human demand, the sustainable use of multiple marine resources is continually challenged. The increasing complexity of overlapping marine activities causes pressures on the environment. Here, we review the fundamental aspects for effective marine management, particularly the role of science and scientific evidence to inform marine policy and decision making. The outcomes of internal expert workshops were used to analyse currently applied marine management practices in the UK using four marine sectors in English waters based on the expertise: environmental impact assessments; dredge and disposal operations; marine protected areas; and offshore renewable energy. Strengths, weaknesses, and commonalities between these sectors were assessed in terms of their effectiveness for marine management. Finally, we make recommendations based on the outputs to better inform effective yet sustainable marine management. The importance of increasing accessibility to data, hypothesis-driven environmental monitoring, streamlining funding opportunities and ensuring effective dissemination of data to ensure scientific outcomes and achieve increased robustness of assessments is emphasised. We also recommend that assessment drivers align with the outputs and approaches should be holistic and engage with the public to ensure a shared understanding and vision.
\end{abstract}

Keywords: marine management; evidence/science policy interface; UK; marine planning; advice; assessment

\section{Introduction}

The marine environment provides a critical set of goods (resources) and services to support human well-being and prosperity, whether for fishing (food), transportation routes (trade), energy, tourism, or waste disposal [1,2]. Increasing human demands means the sustainable use of multiple marine resources is continually challenged by the complexity of overlapping marine activities in time and/or in space, causing growing pressures on the environment [3-5]. Hence, complex spatial management considerations arise if the policy of sustainable development is to be achieved. Integral to effective management, including sustainable use, is a clear process supported by environmental, social, and economic evidence [6] through an ecosystem approach. 
Effective marine management is defined as "management that changes rapidly in space and time in response to the shifting nature of the ocean and its users based on the integration of new biological, oceanographic, social and/or economic data in near real-time" [7]. There is a clear need for technical advice and assessment to ensure marine planning and decision making are accurate, effective, and based on the latest 'state of the art' evidence, helping to underpin policy, regulatory and decision-making processes. However, despite best efforts, in some instances, this is not possible to achieve [8] due to a multitude of reasons such as resourcing and the uncertainty regarding the responses of the marine environment.

It is the prevention of negative consequences that has been the focus of marine management policy and legislative instruments, such as the European Union Environmental Impact Assessment Directive (2014/52/EU) and marine planning regulations (e.g., the EU MSP Directive 2014/89/EU, UK Marine and Coastal Access Act, 2009; Planning Act, 2008). However, all countries also have policies for economic growth and social wellbeing, so there is a clear need to address these goals equitably within any decision-making process, particularly as and when any conflicts arise. Historically, there has been a singlesectoral/project-led approach to managing the marine environment $[6,9,10]$. This has led to conflicts and poor environmental management potentially due to overlooking multiple interacting (cumulative) pressures as they overlap in time and space. In response, there has been a move towards 'plan-led decision making', which puts sustainable development and strategic use of resources at the forefront of marine management, e.g., marine plans [11] and marine spatial planning (MSP). This involves balancing the current and future needs of society with the capacity of marine ecosystems to provide environmental benefits to truly realise 'sustainable development'. The measures imposed to control the COVID-19 pandemic have had repercussions for national and global economies, and the role of sustainable development principles is a crucial component of the recovery. Sustainable use and development require us to safeguard human and animal health whilst enabling food and energy security. This is essential to support (and allow) the growth of marine economies as well as conserving and enhancing biodiversity. The process of marine management brings together regulations, policies, evidence, actions, and organisations (states and nongovernment organisations) in the context of sustainable management. This management requires a broad range of focussed activities to work together to reduce conflicts and achieve the strategic goals of a marine area [12]. There is a tendency for science and policy to be reactive but, with growing knowledge and more integrated environmental policies and legislation, there are aspirations to be proactive, for example through the development and implementation of marine plans [13-16]. Taking a 'plan-led' approach to decision making provides a framework to equitably consider environmental, social, and economic evidence through ecosystem-based management.

There are many competing societal resource needs in the marine area, such as food, energy, trade, transport, and tourism, as well as less tangible but no less important needs, like health, well-being and biodiversity and nature conservation [17]. Some sectors fulfilling these needs must be located where the relevant resources are available, such as aggregate extraction sites. Other sectors or activities need permanent structures such as energy installations, whereas others, for example fishing, are spatially and temporally variable. Some sectors will require use of the sea floor (e.g., cabling)—whereas shipping only requires the surface and parts of the water column, fisheries can require the surface, sea floor and the water column. There are also temporal as well as spatial considerations in the potential coexistence of activities in the marine area. Competing demands can be difficult to manage, MSP is an essential tool in effectively managing marine activities and supports the sustainable use of marine resources [18]. The MSP process aims to bring together regulators, scientists, policy makers and stakeholders in an integrated, all-encompassing system to avoid duplication and conflict and reduce complexity in marine management. It should support sustainable development, balancing current and future needs against the long-term protection of marine ecosystems whilst also providing greater certainty to the 
delivery of societal needs by marine industries. Marine planning processes also need to work across borders and sectors to ensure human activities at sea take place in an efficient, safe, and sustainable way to provide greater certainty for industries as well as delivering improved environmental protection (EU MSP Directive 2014/89/EU).

Figure 1 highlights the role of academic and applied research in understanding human effects on the marine and coastal environment as key to influencing policy and regulations within evidence-based 'plan-led' decision making. The schema presented in Figure 1 describes the flows of evidence through a typical 'plan-led' regulatory/policy decisionmaking process. To be truly effective it is important to conduct evidence evaluation and interpretation before it can be applied as advice into the decision-making process. Applied research is often commissioned to address specific regulatory or policy questions and as such is likely to require a lower degree of alignment before it can be utilised in decision making (shown by the wider light blue arrow in Figure 1), whereas academic research is likely to require a lot of aligning (or additional applied research, left-most blue arrow in Figure 1). Advice must be unbiased, based on the best available evidence and accessible to non-scientists; this is where engagement with stakeholders is critical to the evaluation and interpretation. When advising for policy, scientific evidence must be traceable and repeatable to ensure accountability. Applied research also helps to address gaps identified by policy, regulations, and decision makers. Furthermore, it is important that technical expertise is embedded within the decision-making process. This provides transparency in the process to explicitly show if and where evidence (and technical experts) feed into the decision-making process to help manage accountability, perceptions, and confidence in the outcomes.

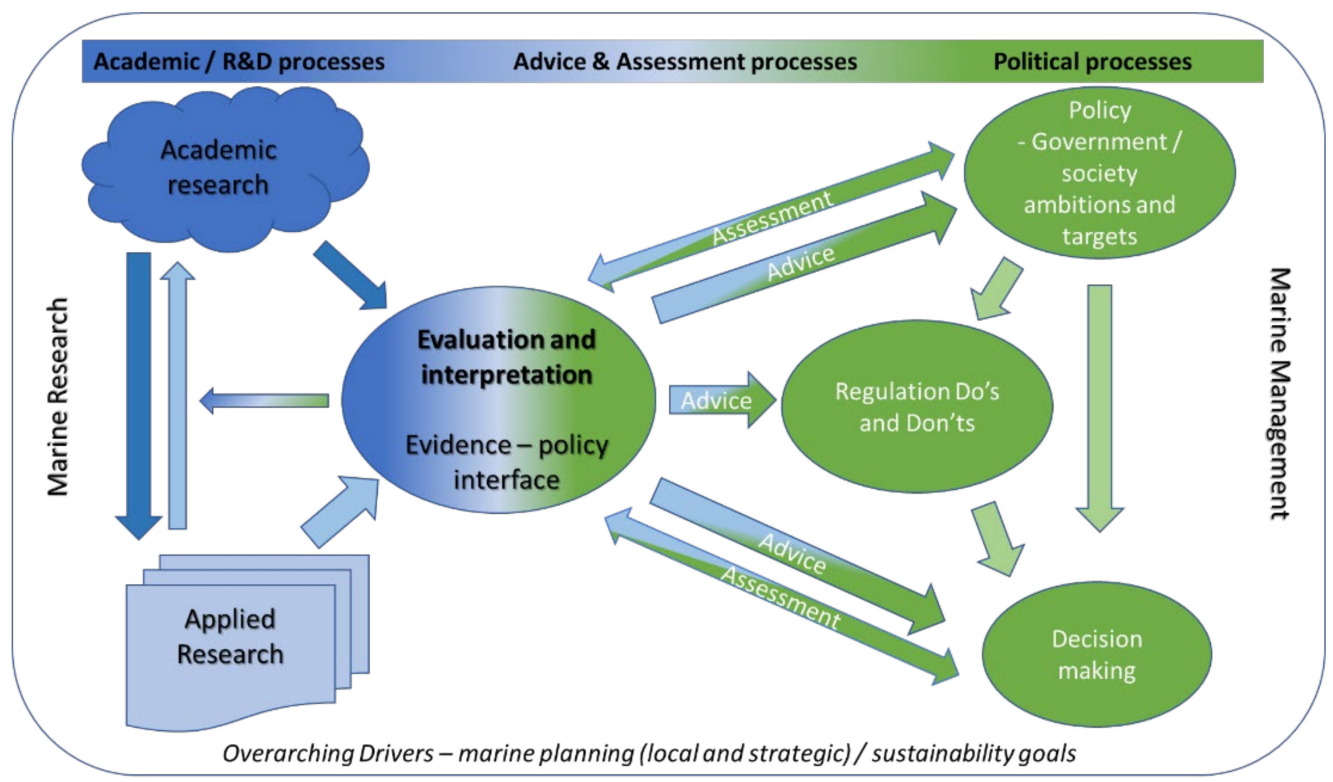

Figure 1. The system and processes involved in marine management decision making highlighting the interacting processes, which link marine evidence from research (represented by dark blue for academic and light blue for applied) to marine policy, regulation, and management (represented by green). Evidence can be environmental, social, economic, or integrated and should include stakeholders in the overall evaluation and interpretation. The arrows are small, medium, and large and describe the relative amount of evidence and feedback used in the processes through the system. The policy aspects are shown in green and should feedback to inform development of appropriate evidence. Academic research often requires context setting within the evidence-policy interface, depicted by the zone in the middle of the schema. The gradient of blue-green highlights the links in the processes where there is both science evidence and political aspects that are required for the decision making. 
This paper focuses on how adopting a 'plan-led' approach to decision making can be successfully achieved if it is centred on appropriate and robust evidence (as outlined in Figure 1). The aim is to show how understanding the component parts of the process is required to ensure an iterative and effective approach of applying evidence to develop an understanding of the marine environmental, social, and economic system is used (as depicted in Figure 1 arrows). Addressing this aim is important for effective marine management towards the goal of sustainable development and contributes to the UN Decade of Ocean Science for Sustainable Development [19]. The UN Decade of Ocean Science for Sustainable Development recognises that marine management requires all these stages to progress towards sustainability, but to make progress, the strengths and weaknesses must be assessed.

We use four case studies to review the key components (Research, Assessments, Monitoring, Regulations and Policy) that are required for effective marine management and assess these components through expert knowledge of practitioners, the evidencepolicy interface role. Centre for Environment, Fisheries and Aquaculture Science (Cefas) expert workshops reviewed four foci (i) environmental impact assessment legislations; (ii) navigational dredging and disposal operations; (iii) marine protected areas; and (iv) offshore renewable energy development, on which the Cefas has extensive expertise and experience of working and advising on issues that are prominent in UK waters. In these four case studies, we review and reflect on the processes of using evidence towards effective marine management and provide analyses of how this is achieved.

\section{Materials and Methods}

A strong science evidence base is vital for the development of robust strategic planning and delivery of legal governance in the marine environment. In the UK, environmental evidence needs are currently met through the provision of expert scientific advice and the commissioning of targeted, public-funded projects. The need for fluid interfaces between science and policy is recognised as vital for effective environmental governance. Governmental scientific organisations have an important strategic position at the interface between marine science and policy through their role as applied scientific advisors. Comprised of technical and scientific experts, these organisations understand political and international governance, and can act as a translator of the evidence, in addition to assessing and considering technical issues. Such expert advisors are required to access the broad spectrum of evidence, from both academic and stakeholder sources, in order to provide rapid responses to inform changing government priorities and management of risks to the marine environment.

The overall process is summarised in Figure 2, and is further explained here. An initial workshop was attended by 15 advisors at the Cefas whose expertise is in applying science (applied and traditional research) to policy. The workshop attendees identified the components and flows of where evidence can be applied to drive, respond, and inform research, assessment, advice, regulation, and policy for marine management (described in Figure 1):

- $\quad$ Research to understand the natural environment applied to inform the sustainable use and development of natural resources.

- Assessments provide either predictive or observed changes. Technical advice takes the outputs of research and assessments and translates these into meaningful outcomes to inform regulation and policy.

- Monitoring/Evaluation to determine if changes have occurred and, if so, to what extent as well as the causes of such changes (and if attributed to human activities, what additional mitigation or intervention may be required).

- Regulations which can both drive the need for evidence (e.g., state of the oceans assessments) and also use evidence as the basis for the need for legislation (e.g., microbead ban). 
- $\quad$ Policy which sets out the aims, objectives, and vision of the government, requiring an understanding of the natural environment, its value, and its uses for society.

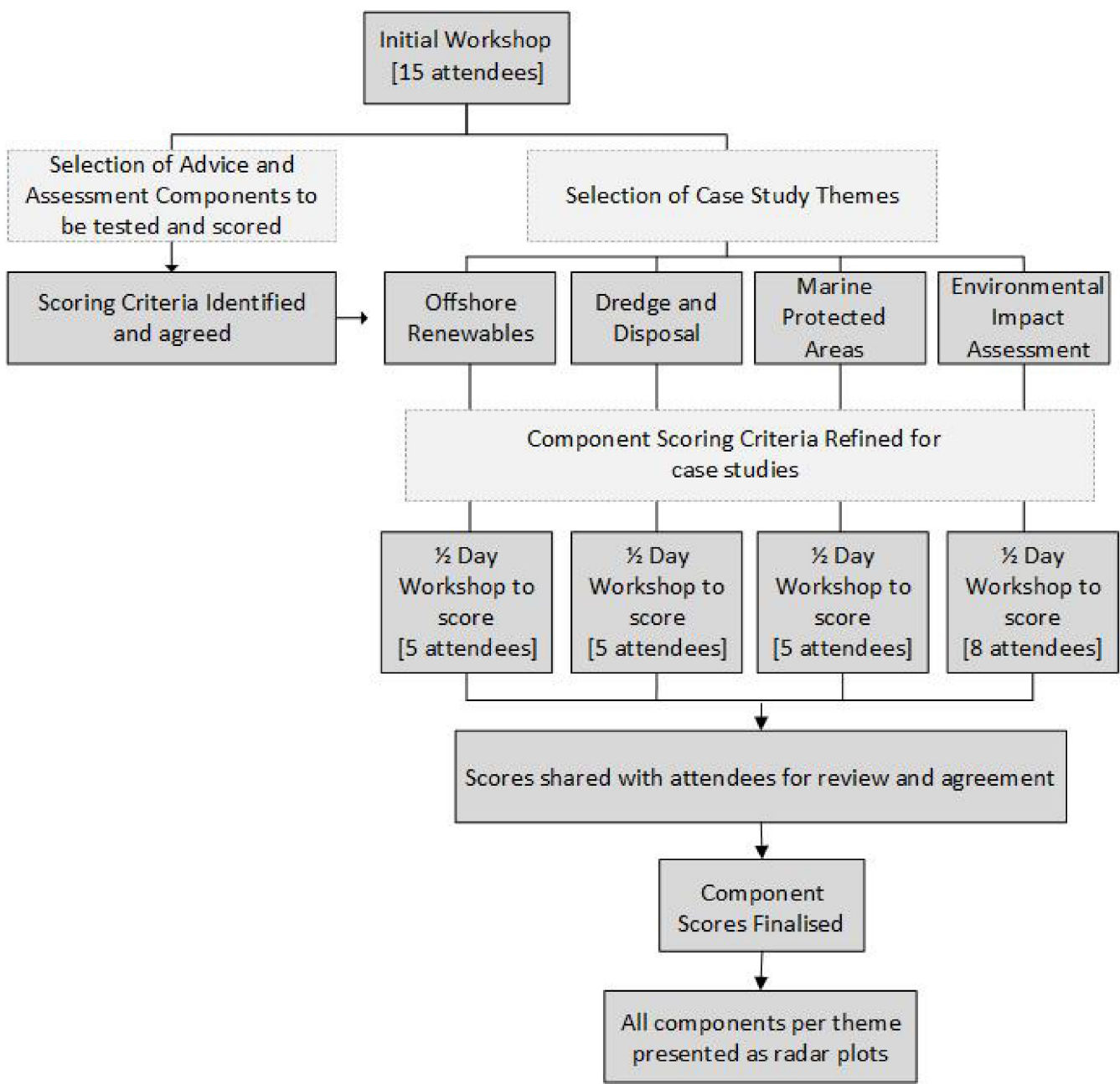

Figure 2. Summary of how this study was progressed. Boxes with solid lines (and dark grey background) represent separate workshops/steps in the process. Boxes with dashed lines (and light grey background) show what was determined in the preceding workshop box, i.e., the initial workshop defined the case study themes to be taken forward.

Each of these five components of marine management relies on the input of evidence to ensure uncertainty is reduced for the decision makers, but it is also important to recognise that there are limits to each aspect and no process is devoid of uncertainty or risk.

During the initial workshop, it was agreed that these five components should be tested, and four case study topics were selected based on the advisors' current research interests and expertise. These steps were taken to show how the science-policy interface works in practice. The broad topic themes (Table 1) were chosen to reflect variation within the different areas required for marine management and activities, and the longevity of these themes.

After the initial workshop, half-day topic-specific workshops were run, where the assessment and advice process, as currently defined (Figure 1), was discussed and scored according to specific elements of the relevant components of the advice and assessment process for each activity. Groups of Cefas science-policy experts of between 5 and 8 experts in each workshop, who regularly apply the process across different themes and sectors, considered the effectiveness of the process, along with a measure of limitations. A facilitator person oversaw all the groups to ensure consistency in the discussions and scoring. 
Table 1. Identifying foci for the case studies.

\begin{tabular}{|c|c|c|}
\hline Foci & Areas of Potential Conflict & Timeliness \\
\hline $\begin{array}{c}\text { Environmental impact assessment } \\
\text { legislation }\end{array}$ & Marine management approach & $\begin{array}{l}\text { The EIA legislation is established but is still } \\
\text { evolving with new knowledge }\end{array}$ \\
\hline Dredge and disposal operations & $\begin{array}{l}\text { Human activities from dredge and } \\
\text { disposal }\end{array}$ & $\begin{array}{l}\text { Dredge and disposal are considered an historic } \\
\text { activity as it has been ongoing for decades }\end{array}$ \\
\hline Marine protected areas process & Legislation & $\begin{array}{l}\text { Marine protected areas are established for their } \\
\text { effectiveness is yet to be quantified }\end{array}$ \\
\hline Offshore renewable energy & Offshore infrastructure (renewables) & $\begin{array}{l}\text { Offshore renewable energy is a relatively new } \\
\text { sector where the technology is still advancing }\end{array}$ \\
\hline
\end{tabular}

The four foci were scored for each of the five key components of marine management (research, assessment, monitoring, regulation, and policy). The scoring (see Appendix A) was undertaken by the same person using the forms (see Appendix B) shared on a computer screen so people could contribute and review throughout the session. The score for each element of the components was assigned by the expert group using the scale 0 (weaknesses) to 4 (strengths; see Appendix A). Where there was overlap between scoring criteria, a score half-way between the criteria was used (e.g., a score of 2.5 between criteria with scores of 2 and 3). Free-form text was added wherever necessary to explain the rationale for the chosen score. On completion, the scores were shared with the group via email for their review and agreement before being finalised by the facilitator.

We visualised the scoring for each foci through radar plots of the scores to be an effective communication tool as well as to capture the different dimensions and the relative strengths and weaknesses. This follows a similar method as [20] as the different components can be viewed together to give a comparative overview. The relative strength (cf. weakness) of each component identified as key to the advice and assessment process of each focal activity is displayed in the radar plots. The analyses of the focal activity workshops are presented in the following case studies. During discussions within the workshop, there were cases where the components used were combined between each of the four cases-the reasons behind this are noted in each case.

\section{Results: Case Studies}

\subsection{Environmental Impact Assessments}

Environmental impact assessments (EIAs) are a core assessment process for enabling management of the impacts of proposals and activities before they are approved under licence. EIA is a method used to inform decisions to be made on what activities can occur where and how. Whilst there are other tools and decision-support systems (such as ecological risk assessment, ecosystem-based management, and marine planning), here the EIA process was assessed due to their being a legal requirement, wide use, and application across marine sectors. EIAs can be used to inform other assessments such as the Habitats Regulation Assessment (HRA) or the Water Framework Directive (WFD) (Directive $2000 / 60 / E C$ ) assessment, as well as a way to identify other relevant parties to consult with (statutory consultees and wider public) during assessment. The scores for EIAs are shown in Figure 3, with the explanation for the scores provided in turn below.

Overall, EIA processes are well established within the UK across the range of marine developments. Research was deemed reasonable for evidence availability and specificity; however, confidence in this evidence was scored low (Figure 3a). The Assessment component is generally good; however, again, confidence in the assessment was a lower score. Monitoring and regulations were scored as strong except for the element of reviewing monitoring within the regulations (i.e., learning from monitoring outputs and adapting). The low score in Figure $3 \mathrm{~d}$ is a consequence of the regulations only being reviewed on a periodic basis-it does not mean that the regulations are weak. However, regulations are reviewed and updated as and when knowledge advances, such as the most recent update to the EIA Directive introducing the impact of climate change. The Policy was considered 
as strong, although public understanding could be improved (Figure 2e). So, whilst EIA in general is well established, there were some weaknesses that should be addressed to strengthen EIA as a tool.

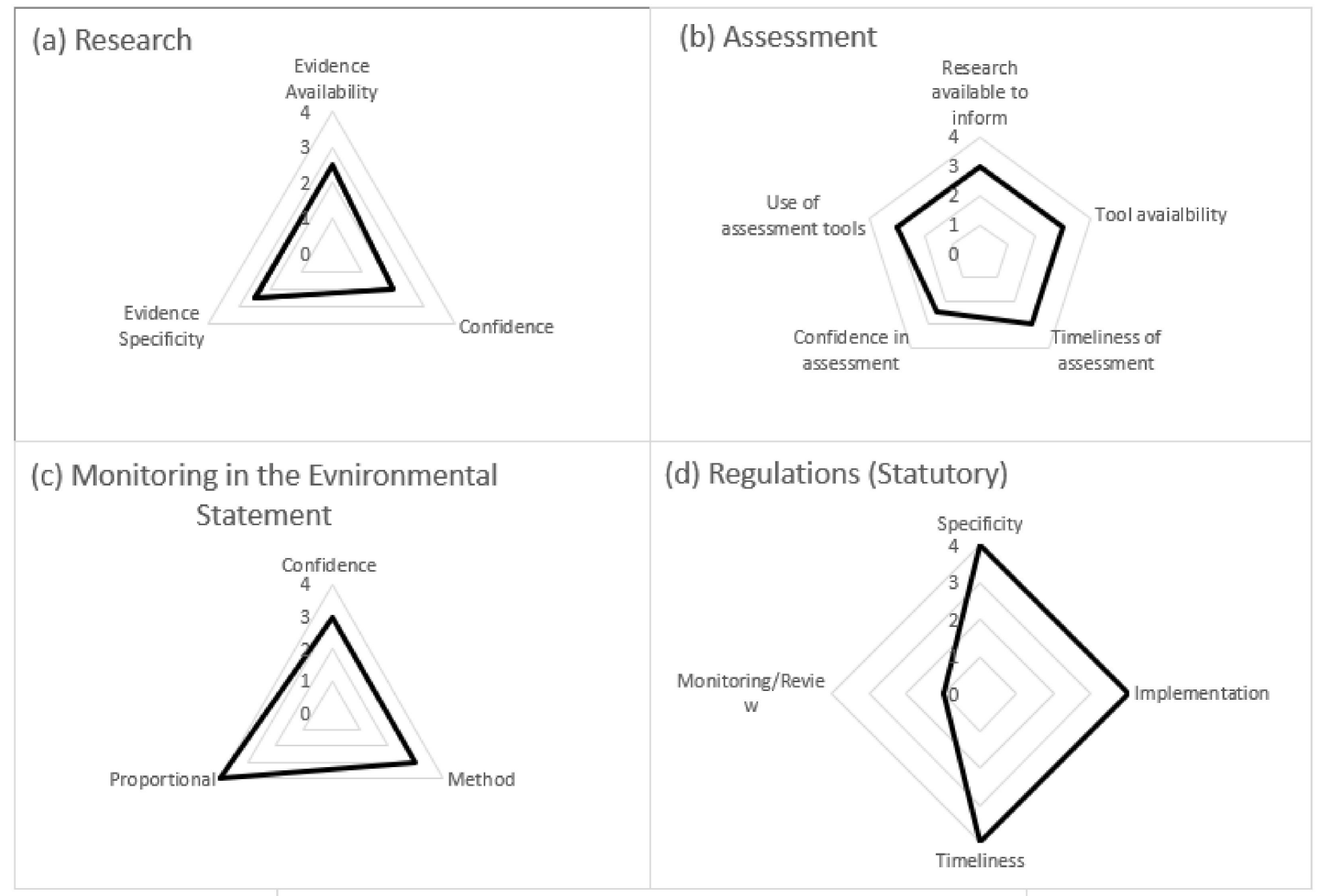

(e) Policy (Drivers)

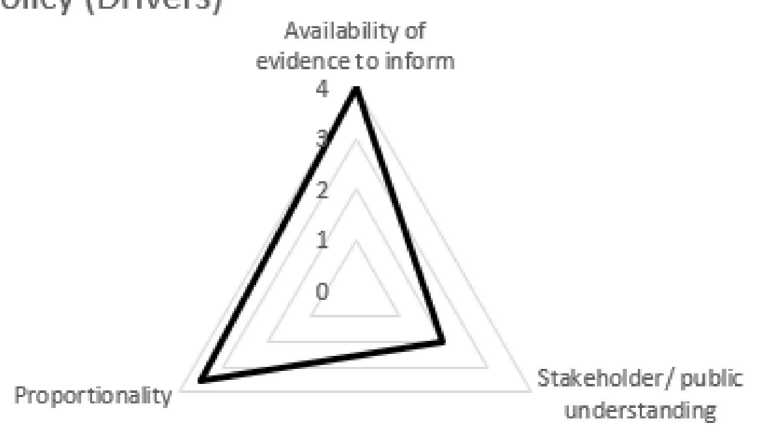

Figure 3. Radar plots showing the strengths and weaknesses for the different elements of the five components relevant to environmental impact assessments. 0 means no confidence or evidence, whereas 4 means excellent confidence and/or evidence. Details for the score rationales are provided in the Appendices A and B.

What was recognised during the exercise was that with emerging developments (e.g., tidal lagoons) in areas not previously considered for development (e.g., floating wind installations being placed further offshore), or new knowledge (e.g., the effects of increasing ocean acidification), there are a wider range of topics for which we have limited understanding of the impacts, which has knock-on effects on environmental assessments. 


\subsection{Dredge and Disposal Operations}

Dredging for transport and reclamation purposes has been carried out for decades, resulting in a wealth of published evidence on its effects [21,22] (represented by high scores in Figure 4a). To accommodate the growing demands associated with increased offshore development and the use of larger commercial vessels using ports, there is an increasing need for dredging and dredged material disposal as components of construction of new infrastructure. Dredging and the disposal of dredged material to sea (including for beneficial use) are governed by both national regulations and international obligations. Figure 4 shows the scoring outputs for dredge and disposal.

(a) Research base

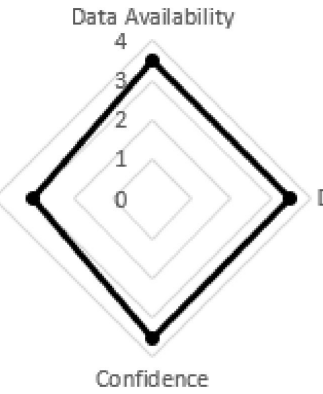

(b) Assessment

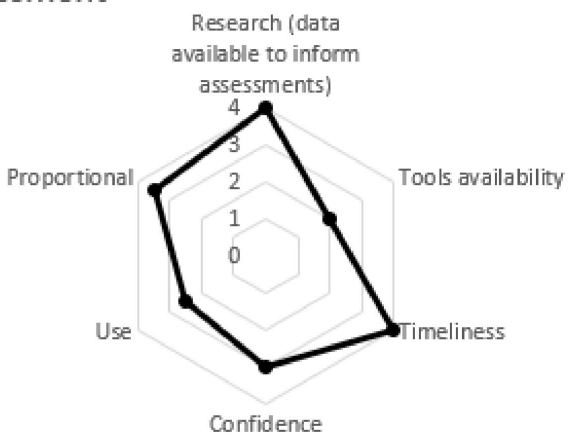

(d) Regulations (Statutory)

\section{(c) Monitoring}

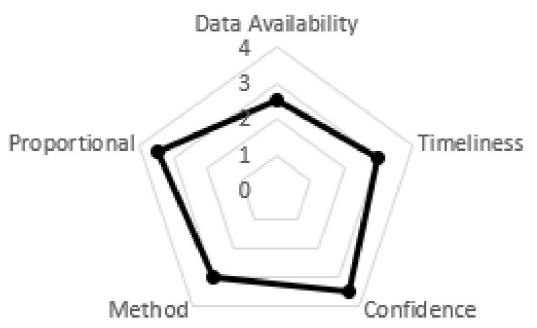

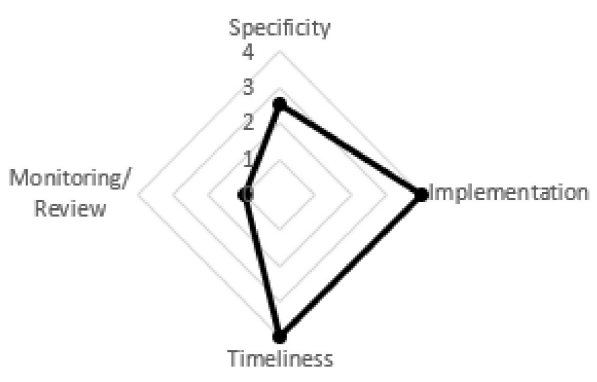

(e) Policy

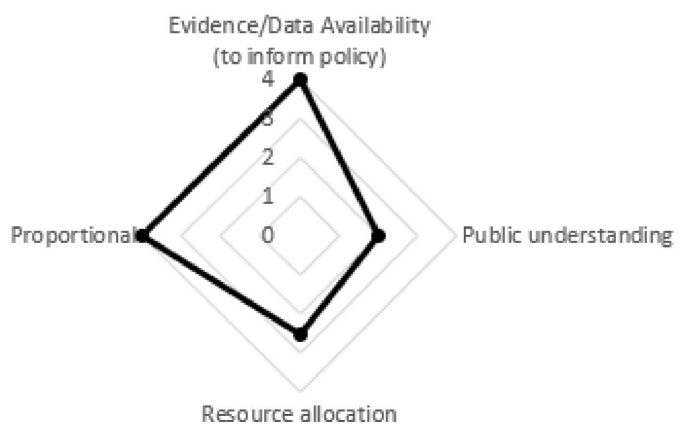

Figure 4. Radar plots showing the strengths and weaknesses for the different elements of dredge and disposal operations. 0 means no confidence or evidence, whereas 4 means excellent confidence and/or evidence. Details for the score rationales are provided in the Appendices A and B.

Similar to EIA, dredge and disposal operations are well established, although there have been changes in recent years with the expansion of offshore wind farm array areas and cable corridors being designated as disposal sites to comply with The Convention for the Protection of the Marine Environment of the North-East Atlantic (OSPAR Convention) 
and London Convention/London Protocol treaties given that sediment is being moved and disposed through sandwave levelling and other sea-bed preparation works.

All aspects of research relating to dredge and disposal were regarded as a strength (Figure 3a), which then fed through to the availability and timeliness for assessment (Figure $3 \mathrm{~b}$ ) and further to policy evidence and proportionality (Figure 3d). Monitoring overall had higher scores but identified a need for data being more available (Figure 3c). There were some areas of apparent weakness. The tools available for assessment include mapping software, international guidelines, and implementation of thresholds to indicate sediment (contaminant) toxicity but these all require expert judgement, especially the thresholds which are not pass/fail and therefore open to subjectivity (Figure 3b). Whilst there is a general understanding across national experts about the use of these tools, there can often be differences in the interpretation of results in respect to these thresholds.

The regulations which regulate dredge and disposal activities were scored low for 'Monitoring/Review' (Figure 3d) for similar reasons to the EIA regulations: there is no frequency for review defined in the regulations and is at the discretion of the Competent Authorities. It is recognised that updating legislation is costly and is therefore carried out when there is a major shift in understanding. Therefore, no recommendations are made here because the regulations are updated when the science or policy dictates a change is needed, although it is noted that any new provision will need to be tested once implemented.

That last area of weakness was regarding public understanding of dredge and disposal operation policy (Figure 3e). All policies are subject to public consultation but there is limited understanding of the specific needs and assessments, or how these can be driven by policy and/or social science. The approach taken for dredge and disposal operations is driven by national legislation and international treaties and guidance which the public may not be aware of.

\subsection{Marine Protected Areas}

Marine protected areas (MPAs) are part of a range of tools used for the protection of UK waters. There are three types of MPA which contribute to the ecologically coherent network of MPAs in English waters: Marine Conservation Zones (MCZs); Special Protection Areas (SPAs); and Special Areas of Conservation (SACs). There are currently 357 MPAs in UK waters, protecting $36 \%$ of the UK's seas and spanning $318,248 \mathrm{~km}^{2}$ [23].

MCZs are designated under the Marine and Coastal Access Act 2009 to protect nationally representative and rare or threatened species and habitats. SPAs and SACs are currently designated under the EU Wild Birds and EU Habitats Directives, respectively. SPAs protect areas identified as being of international importance for the breeding, feeding, wintering or the migration of rare and vulnerable bird species found within Europe. SACs protect areas of habitat, or areas which are of key importance to species (excluding birds) which have been identified as requiring conservation at a European level.

Scores are provided in Figure 5. The monitoring and assessment components were combined because of their intrinsic nature in the designation and management of these protected areas, i.e., initial monitoring is required for the assessment to be undertaken and the conservation status to be determined, but the assessments undertaken also inform the frequency of subsequent monitoring.

Marine protected areas now cover a large proportion of the UK's marine area and, whilst research is undertaken to answer specific questions or knowledge gaps, the analysis indicates that the availability of evidence and the quality of the data are variable. This is reflected in the low scores of the 'Research', 'Monitoring/Assessment' and 'Policy (Drivers)' components, Figure 4a,b,d, respectively. A further complication is that often data are known to exist, but they cannot be obtained easily to inform assessments, thereby hindering their effectiveness and efficiency within the process. It is recognised that all research data should be stored on public databases to help with access for user development input to make the process easier. 


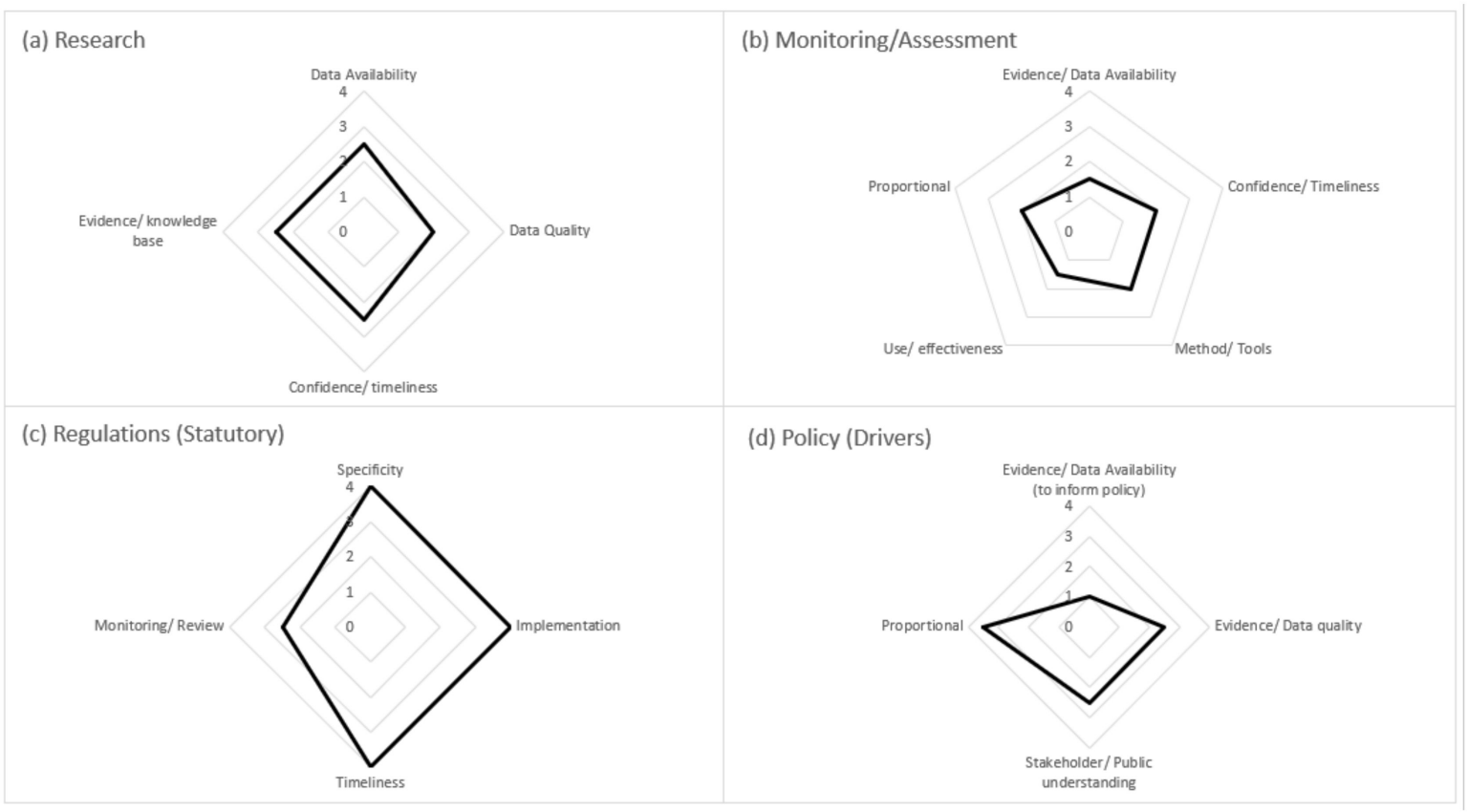

Figure 5. Radar plots showing the strengths and weaknesses for the different components of marine protected areas. 0 means no confidence or evidence, whereas 4 means excellent confidence and/or evidence. Details for the score rationales are provided in the Appendices A and B.

A key factor for data quality is the data that are collected during monitoring to assess the overall quality of the MPA site and its features. The thematic area for 'Monitoring/Review' Figure 4c, was scored low because of how recent some designations are, and the size of the task to monitor all MPAs on a regular basis. Some monitoring is prioritised to help fill some gaps in knowledge which were present at the designation stage; however, this cannot be improved, since MCZs have statutory timelines for designation. Defra and its advisors do, however, have specific guidance for the quality of acceptable data and the minimum level of evidence required [24,25]. Priority monitoring is required to focus efforts on those sites of most concern (not reaching favourable status, or similar) or those with higher uncertainty, but all monitoring should be hypothesis driven and linked to appropriate conservation objectives and/or management measures. Such implementation would strengthen all the components in Figure 5a-d.

\subsection{Offshore Renewable Energy Developments}

In 2019, the UK became the first major economy to implement climate change legislation for Net Zero $\mathrm{CO}_{2}$ by 2050 [26]. An important factor to reaching this target is finding alternative sources for energy production from hydrocarbon-based sources. A key resource has been the marine environment. Currently, there are 38 leases with operational offshore wind farms with a generating capacity of 7905 [27]. New phases of development have been announced and, alongside other marine renewable energy developments, it is envisaged that the marine renewable energy sector will continue to be a major contributor to reaching this ambitious target. The scores are provided in Figure 6 and discussed below.

Offshore renewable energy developments are still a relatively new industry, with the UK's first major offshore wind farm becoming fully operational in 2003 [28]. This is evident when considering the scores. Data availability for research aspects was scored as 'poor', as there are many questions that have been posed and not all have received research attention. For those areas that are investigated, the data are not always freely available (Figure 6a). For those aspects that are required to be monitored, the score was relatively high under 'Monitoring' (Figure 6c). This was a result of high levels of monitoring when the industry was in its infancy to address uncertainty (hence why 'proportionality' was scored relatively 
low; Figure 6c). Under 'Research', data quality scores relatively high because, again, new areas of industry, especially those that set out to tackle a global problem such as climate change, attract funding to address issues despite some progress to address these over the last two decades. Overall, there were certain elements which scored low, and some reasons are stated as being similar to the other case studies. Data scored low in 'Research' (Figure 6a) for similar reasons as EIA and MPAs, i.e., the data are being collected, but it is not easy to find unless you are aware of its existence and is not always free to access.

(a) Research

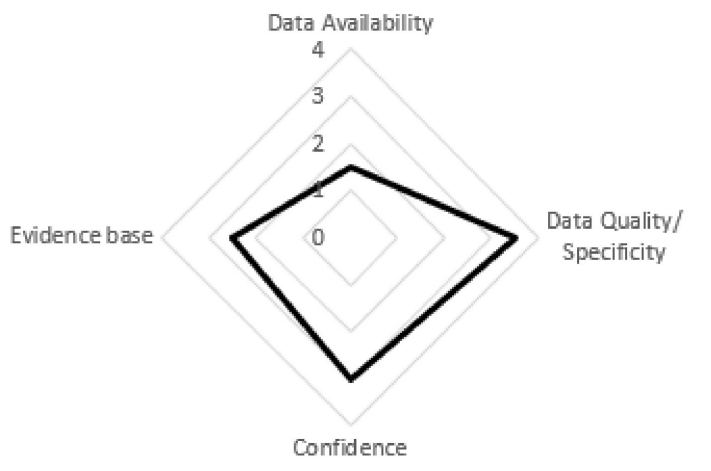

(c) Monitoring

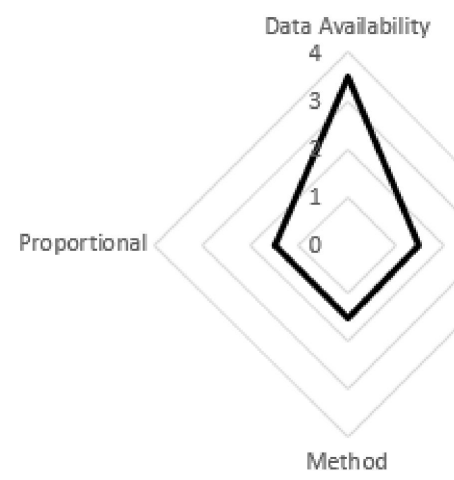

\section{(b) Assessment}

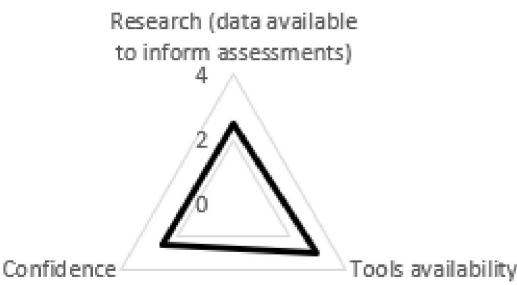

(d) Regulation (Statutory)

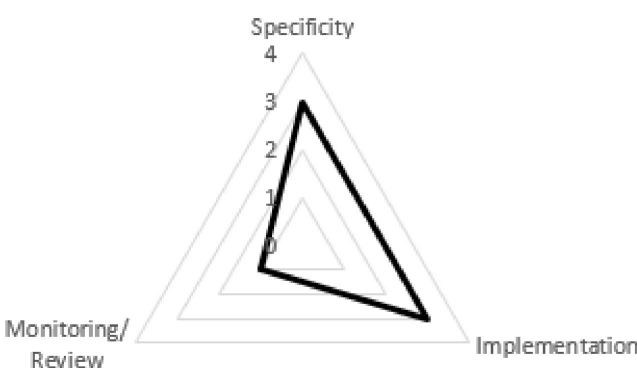

(e) Policy (Drivers)

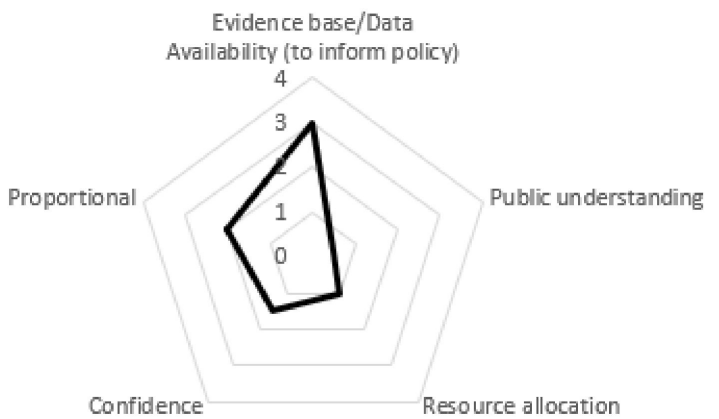

Figure 6. Radar plots showing the strengths and weaknesses for the different elements of offshore renewable energy developments. 0 means no confidence or evidence, whereas 4 means excellent confidence and/or evidence. Details for the score rationales are provided in the Appendices A and B.

Monitoring data collection should always be hypothesis driven and follow best practice; however, some decisions are driven by cost or legacy. For example, monitoring all 
environmental aspects every year, or multiple times a year would be disproportionally costly; therefore, often a compromise is reached to inform monitoring assessments (e.g., focusing benthic monitoring to areas of impact from seabed disturbance rather than a grid survey design comprising the entire site [29]). Any such limitations in data collection should be noted at the start of the process to understand what questions the monitoring is likely to be able to answer. There are also outstanding issues regarding understanding potential impacts because for newer industries, there are not enough monitoring data collected to determine long term impacts.

Policy, as a whole, scored relatively low (Figure 6e) because while there are policies in place and steps to increase the resource to support this industry from the government, there is little public understanding regarding the complexities of the environment and development that are required to be assessed and balanced by the regulators. Furthermore, policy development requires stakeholder engagement and public education on the marine environment and sectors as a whole, and there is no single approach or "quick fix" to resolve this.

The policies surrounding reducing greenhouse gas emissions and increasing renewable energy production have been largely developed based on international goals and targets, but this may not be achievable in the UK due to technological status, regulatory burden, equitability between environmental, social, and economic issues in decision making (e.g., achieving net gain for biodiversity, tackling climate change and sustainable renewable energy) or uncertainty in the underpinning science.

\section{Discussion}

Science-based evidence is clearly a core aspect of the decision-making system which feeds into marine policy, regulation, and management. Through the assessment of the four different focal activities by those involved in policy assessment and transfer of scientific knowledge, it was shown that overall there is a medium to high confidence (i.e., high scores) in the process(es) leading to marine management in the UK. However, there are important exceptions within each activity and across components of the process, and there are lags in incorporating new evidence into regulatory frameworks. The research that is undertaken in the UK, scored highly across all four activities, although data availability scored lowest under the offshore renewable energy activity. This is due to the wide range of issues that need to be considered for this sector (e.g., benthos, fish, birds, marine mammals, hydrographic conditions, contaminants, and underwater noise) and that our understanding of the impacts (regionally and cumulatively) is still in development. For all four case studies, some of the data are publicly available, either because the activity is driven by the UK government or because of the regulations, i.e., EIAs, must be available for the stakeholders to review and comment on. However, due to the competitive nature of offshore industries, it is unlikely that the raw data will be readily, easily, and freely available without the influence of the regulators and legislation forcing the operators to do so. For example, The Crown Estate lease requirements require data to be in the public domain, although there is often a time lag in their availability.

There was a similar overall trend in the assessment component of the analysis, with all activities scoring above ' 2 ' for all elements, except for MPAs. For the other activities, the scores are indicative of the established regulations that underpin these activities and their longevity. In the case of MPAs, monitoring and assessment were combined due to the intrinsic nature of these for the designation and management of these areas. Generally, management related to MPAs in terms of assessment and monitoring is ranked "low" at present owing to the extensive network requiring surveys and evaluations and their effectiveness have yet to be demonstrated, especially in terms of pressures such as climate change.

While it is recognised that the theme of 'human activities' is broad, here we have demonstrated the utility of assessing sectors in a consistent manner and communicating clearly the strengths and weaknesses and, as such, this method could be used to assess other activities such as fishing, gas and oil exploitation, and seabed mining. 
While the research and assessment component scores were similar, monitoring scores varied within each activity component. For instance, the methods used in monitoring of offshore wind farms scored "low" due to some monitoring not being hypothesis driven, or not being fit for purpose. For example, the effects on some receptors may take decades to manifest and require data to be collected for periods longer than the duration of a licence. This in turn led to lower scores for proportionality and confidence for offshore wind activity. Monitoring for dredge and disposal, and EIA generally scored "high", and this is indicative of established methods due to the longevity of the activities and trends being available over time. Whilst it is acknowledged that not all areas of uncertainty can be monitored or investigated, and there will be some level of uncertainty remaining, priorities are likely to target the activities which posed highest risks, e.g., those leading to cumulative effects, or on a larger geographic scale.

To manage the marine environment, the UK has established regulations, and the majority of marine activities are managed under the same regulations (Marine and Coastal Access Act 2009 (MCAA), Marine EIA Work Regulations; Planning Act). It is of note that the activities considered here are all managed under one or more of these regulations. As such, the scores were consistent across the activities, generally scoring "high", but with all activities scoring lower on the monitoring/review elements as they referred to the same regulations.

There are many more policies in place than regulations in order to set the ambitions and targets for the protection and use of the marine environment, hence the scores for policies across the activities varied. As with assessments and monitoring, the more established activities (dredge and disposal operations and EIA) scored higher than newer activities (offshore renewable energy developments and MPAs). Even between offshore renewable energy developments and MPAs, there were differences in that offshore renewable energy developments scored higher for the evidence base, and this tends to be because data are presented more timely (by the developer) and considered more robust in comparison to the evidence available for MPAs. MPAs have a higher level of stakeholder and public understanding due to a 'bottom up' approach where citizen science and the requirements for public consultation under the regulations play a larger role.

Overall, whilst there were some similarities across activities, the longevity of the projects occurring under the activities differed, which makes effective and holistic marine management policy challenging. To address this, the weaknesses identified above should be considered further to strengthen them and consequently increase confidence in marine management advice and assessment.

Common themes for improvements in marine management which came from the workshop outputs and analysis, and align with the priorities of the UN Decade of the Ocean Science for Sustainable Development for collaboration and an integrated management approach [19], were:

1. Data accessibility: by having academia, industry and government share data platforms, with such platforms being more integrative for the combination of data sources and signposting to allow easier searches beyond the current situation.

2. Streamline funding opportunities: using UK Research Council workshops and the Offshore Renewables Joint Industry Programme (ORJIP) as examples to call for scientifically robust policy and applied ideas in order to scope funding calls and then assess proposals.

3. Driver and output alignment: to reduce unnecessary effort put into unwieldy reports which do not communicate the project and results effectively, but rather the provision of better/sharper products that allow the outputs to be more widely and consistently used and applied.

4. Effective dissemination: by having round table discussions between advisors and regulators for an effective planning dialogue, leading to a more holistic approach to understanding and managing the marine environment. 
5. Ensure holistic approaches: to science, policy, regulation, and legislation to ensure the ecosystem-based approach to management is applied.

6. Ensure Monitoring is hypothesis driven: and continue to monitor and assess new activities such as MPAs or floating offshore wind farms.

7. Public engagement: so the public have a clearer understanding of why the government has certain policies and commitments, and how these interlink (i.e., the drive for increased offshore renewable energy production and the need to protect $30 \%$ of our seas).

Sustainable governance of the ocean demands a more integral and dynamic role for evidence. There are many examples of how the use and application of a sound evidence base has been essential to governance on regional scales, particularly when there is strong scientific consensus, clear identification of problems and solutions, and a convergence of cultural ideas. Evidence is especially needed to contribute to: understanding intergenerational and interspatial effects, addressing inherent uncertainty about the behaviour of marine ecosystems, and integrated ecological-economic models and assessments needed for adaptive management. However, the full image is not complete as there will be other aspects that will have to be incorporated into this iterative process (e.g., climate change) [8] and other emerging challenges (e.g., decommissioning of human-made structures; see [30]).

\section{Conclusions}

This paper has provided an overview of what is required for effective advice and assessment associated with marine management and how evidence is required at all stages. A series of focussed workshops were undertaken using Cefas experts on four different marine activities to identify the current strengths and weaknesses of the assessment and advice process and the utility of evidence to that process. It is recognised that this study was driven by experts within one organisation and only on four case study sectors, but the approach used can be applied across the broad spectrum of human activities and by other organisations.

Overall, there was medium to high confidence in the process(es), leading to marine management in the UK; however, the scoring for the components across the sectors varied, with the longer established sectors generally increasing in confidence, although not always. To alleviate this, we have made recommendations based on the review and analyses to better inform effective yet sustainable marine management, including increasing accessibility to data, ensuring monitoring is hypothesis driven, streamlining funding opportunities and ensuring effective dissemination so all can benefit from the scientific results and more robust assessments can be made. Additionally, we recommend that drivers should align with the outputs and any approaches should be holistic and engage with the public to ensure a shared understanding and vision.

Author Contributions: Conceptualisation, J.-A.L., A.G. and S.N.R.B.; methodology, J.-A.L. and A.G.; validation, A.J.; writing — original draft preparation, J.-A.L., A.B.G., K.A., S.N.R.B., S.B., H.B., C.C., S.C., N.E., L.F., F.G., A.G., A.J., R.M., J.P., K.R. and D.W.; writing-review and editing, J.-A.L., A.G. and S.N.R.B.; supervision, J.-A.L.; funding acquisition, S.N.R.B. All authors have read and agreed to the published version of the manuscript.

Funding: This research was funded by the Cefas, under 40101A.

Institutional Review Board Statement: Not applicable.

Informed Consent Statement: Not applicable.

Data Availability Statement: Not applicable.

Conflicts of Interest: The authors declare no conflict of interest. 


\section{Appendix A. Criteria for Scoring Advice and Assessment Components}

The generic criteria for the five components identified as required within the advice and assessment process was applied to all four focal activities. First, the components specifically relevant to the focal activity to be scored were selected by the expert group. Subsequently, the score for each selected component was assigned using the scale 0 (weaknesses) to 4 (strengths). Where there was overlap between scoring criteria, a score half-way between the criteria was used (e.g., a score of 2.5 between criteria with scores of 2 and 3). Free-form text was added wherever necessary to explain the rationale for the chosen score. From the scores, radar plots were produced.

Table A1. Data/Evidence Accessibility.

\begin{tabular}{ll}
\hline 0 & No data available \\
1 & Data are stored but not publicly available \\
2 & Data are publicly available but for a fee \\
3 & Data are publicly and freely available, but metadata are not available or not intuitive. \\
4 & Data are publicly and freely available including all metadata \\
\hline
\end{tabular}

Table A2. Data/Evidence Quality/Specificity.

\begin{tabular}{ll}
\hline 0 & Data are not accurate, complete, reliable, relevant and are not up to date \\
1 & Data are relevant, timely and complete but not accurate \\
2 & Data are accurate but not timely nor complete \\
3 & Data are accurate, relevant, and timely but not complete \\
4 & Data are accurate, complete, reliable, relevant, and up to date \\
\hline
\end{tabular}

Table A3. Timeliness.

\begin{tabular}{|c|c|}
\hline 0 & No data exist \\
\hline 1 & Data are considered too old for the variable being assessed \\
\hline 2 & $\begin{array}{l}\text { Data are older than expected * for the receptor, a simple justification for newer data } \\
\text { have been provided }\end{array}$ \\
\hline 3 & $\begin{array}{l}\text { Data are older than expected * for the receptor but a full justification for newer data } \\
\text { have been provided }\end{array}$ \\
\hline 4 & Data are timely for the variable being assessed \\
\hline
\end{tabular}

Table A4. Confidence (adapted from [31]).

$\begin{array}{ll}0 & \text { No data on which to base decisions. } \\ 1 & \text { The data are limited and not well supported by evidence. Experts do not agree. } \\ \text { Outdated or inappropriate, not fit for purpose. } \\ \text { The data are limited and/or proxy information. There is a majority agreement } \\ \text { between experts; however, evidence is inconsistent and there are differing views } \\ \text { between experts. }\end{array}$

${ }^{*}$ It is acknowledged that this is subjective between experts; however, the criteria could not be specified further to acknowledge that for some receptors, geological data, decadal data may be appropriate, whereas, for others, such as fish presence and abundance, more recent data are required. 
Table A5. Specificity [of regulations].

\begin{tabular}{ll}
\hline 0 & No regulations or policy in place \\
1 & No regulations in place but there are policy ambitions around the \\
2 & receptor/impact/threat \\
3 & Activity/theme is regulated under generic regulations \\
4 & Regulations have been specifically enacted to address the receptor/impact/threat \\
\hline
\end{tabular}

Table A6. Research (data available to inform assessments).

\begin{tabular}{ll}
\hline 0 & No data available \\
1 & Data are stored but not publicly available \\
2 & Data are publicly available but for a fee \\
3 & Data are publicly and freely available, but metadata are not available or not intuitive \\
4 & Data are publicly and freely available including all metadata \\
\hline
\end{tabular}

Table A7. Tool Availability.

\begin{tabular}{ll}
\hline 0 & $\begin{array}{l}\text { No tools, frameworks, or guidance available to inform assessment } \\
\text { Generic tools, frameworks or guidance are available but not specific to the } \\
\text { assessment }\end{array}$ \\
2 & $\begin{array}{l}\text { Specific tools, frameworks and/or guidance available to inform assessments but } \\
\text { have not been tested }\end{array}$ \\
3 & $\begin{array}{l}\text { A specific tested single tool, framework and/or guidance is available to inform } \\
\text { assessments }\end{array}$ \\
4 & Specific tested tools, frameworks and/or guidance available to inform assessments \\
\hline
\end{tabular}

Table A8. Method.

\begin{tabular}{ll}
\hline 0 & No scientific, rigorous, or justified method has been applied. \\
1 & Method applied but no justification and not based on current best practice \\
2 & Method applied which is no best practice, but justification provided \\
3 & Method applied which is based on a previous best practice or on a low-cost option \\
4 & Best practice has been applied.
\end{tabular}

Table A9. Proportional [monitoring].

\begin{tabular}{ll}
\hline 0 & $\begin{array}{l}\text { No monitoring } \\
\text { Monitoring is required but all monitoring being carried out is under what is } \\
\text { expected or over burdensome }\end{array}$ \\
2 & $\begin{array}{l}\text { Monitoring is required and some of the monitoring being carried out is under what } \\
\text { is expected or over burdensome }\end{array}$ \\
3 & $\begin{array}{l}\text { Monitoring is required and mostly, the monitoring is proportional } \\
4\end{array}$ \\
\hline
\end{tabular}

Table A10. Implementation.

\begin{tabular}{ll}
\hline 0 & No aspect has yet been implemented \\
1 & Policy/regulation has begun to be implemented, i.e., first steps such as organisation \\
2 & Phablishment \\
3 & Partial implementation \\
4 & Full implementation has been achieved \\
\hline
\end{tabular}


Table A11. Monitoring/review.

\begin{tabular}{ll}
\hline 0 & No monitoring or review of the policy/regulation \\
1 & Monitoring and/or review is carried out as required \\
2 & Monitoring and/or review is carried out every ten years \\
3 & Monitoring and/or review is carried out every five years \\
4 & Monitoring and/or review is done on an annual basis \\
\hline
\end{tabular}

Table A12. Public understanding.

\begin{tabular}{ll}
\hline 0 & No public awareness or understanding \\
1 & Public aware of issue but no understanding \\
2 & Public aware of issue and with limited understanding \\
3 & Public aware and understand the issue \\
4 & Public are actively engaged in the issue \\
\hline
\end{tabular}

Table A13. Resource allocation.

\begin{tabular}{ll}
\hline 0 & No resource allocated to implement \\
1 & $\begin{array}{l}\text { Under resourced to allow full implementation } \\
\text { Resource available to implement but with no flexibility to accommodate increases in } \\
2\end{array}$ \\
3 & $\begin{array}{l}\text { Work } \\
\text { Resource available to implement but with limited flexibility to accommodate } \\
\text { Resource available to implement including flexibility to accommodate increases in } \\
\end{array}$ \\
\hline
\end{tabular}

\section{Appendix B. Summary Tables for Case Studies}

These tables, taking each case study topic in turn, provide the score for each thematic area and element along with the justifications. These informed the radar plots in the Case Studies section

Table A14. Environmental Impact Assessments.

\begin{tabular}{|c|c|c|c|c|c|c|}
\hline $\begin{array}{l}\text { Thematic } \\
\text { Area }\end{array}$ & Element & Score & Rationale/Justification & $\begin{array}{c}\text { Limitations/Gaps } \\
\text { Examples }\end{array}$ & $\begin{array}{c}\text { What This Means in } \\
\text { Practice }\end{array}$ & $\begin{array}{l}\text { Recommendations for } \\
\text { Improvement }\end{array}$ \\
\hline Research & $\begin{array}{c}\text { Data } \\
\text { availability }\end{array}$ & $2-2.5$ & $\begin{array}{l}\text { The results of the } \\
\text { data analysis and } \\
\text { methods used are } \\
\text { available to the } \\
\text { public. }\end{array}$ & $\begin{array}{l}\text { Some data used in EIAs } \\
\text { are not publicly available } \\
\text { or may not be easy to } \\
\text { access. }\end{array}$ & $\begin{array}{l}\text { It may be difficult for } \\
\text { interested parties outside } \\
\text { of formal advisors or } \\
\text { statutory bodies to have } \\
\text { confidence in the types of } \\
\text { data used to inform } \\
\text { assessments. }\end{array}$ & $\begin{array}{c}\text { Some data are not able to } \\
\text { be shared publicly and } \\
\text { we must respect data } \\
\text { protection laws. } \\
\text { Signposting interested } \\
\text { parties to where public } \\
\text { data are available will } \\
\text { help with access issues } \\
\text { more generally. }\end{array}$ \\
\hline Research & $\begin{array}{l}\text { Data qual- } \\
\text { ity/specificity }\end{array}$ & $\mathrm{N} / \mathrm{A}$ & \multicolumn{4}{|c|}{$\begin{array}{l}\text { This is not considered here as a separate thematic topic area as it is captured under Evidence/knowledge } \\
\text { base and Assessment } \\
\text { N/A }\end{array}$} \\
\hline Research & Confidence & $2-2.5$ & $\begin{array}{c}\text { Developers } \\
\text { undertake } \\
\text { site-specific surveys } \\
\text { on which to base } \\
\text { the EIA. }\end{array}$ & $\begin{array}{l}\text { Certain topics/industries } \\
\text { have higher uncertainty. } \\
\text { Apply a receptor-based } \\
\text { assessment. } \\
\text { Empirical data used in } \\
\text { modelling often have a } \\
\text { higher level of confidence } \\
\text { assigned to it than other } \\
\text { forms of data especially } \\
\text { where biological factors } \\
\text { affect reliability, e.g., } \\
\text { herring spawning } \\
\text { grounds. }\end{array}$ & $\begin{array}{l}\text { Site-specific data are vital } \\
\text { to collect as each } \\
\text { development is different } \\
\text { and will have different } \\
\text { impacts based on location. } \\
\text { Applying a } \\
\text { receptor-based assessment } \\
\text { is useful as it is easier to } \\
\text { obtain site-specific data } \\
\text { focussed on specific } \\
\text { receptors. However, it } \\
\text { may miss more indirect } \\
\text { impacts and larger } \\
\text { scale/cumulative impacts. } \\
\text { See below for uncertainty. }\end{array}$ & $\begin{array}{l}\text { A requirement for a more } \\
\text { mature science } \\
\text { understanding where } \\
\text { gaps remain including at } \\
\text { the cumulative/larger } \\
\text { geographical scale. }\end{array}$ \\
\hline
\end{tabular}


Table A14. Cont.

\begin{tabular}{|c|c|c|c|c|c|c|}
\hline $\begin{array}{l}\text { Thematic } \\
\text { Area }\end{array}$ & Element & Score & Rationale/Justification & $\begin{array}{l}\text { Limitations/Gaps } \\
\text { Examples }\end{array}$ & $\begin{array}{c}\text { What This Means in } \\
\text { Practice }\end{array}$ & $\begin{array}{l}\text { Recommendations for } \\
\text { Improvement }\end{array}$ \\
\hline Research & $\begin{array}{l}\text { Evidence/ } \\
\text { knowledge } \\
\text { base }\end{array}$ & $2-2.5$ & $\begin{array}{l}\text { Some species } \\
\text { (receptors) and } \\
\text { impacts (from } \\
\text { activity) are subject } \\
\text { to more research: } \\
\text { e.g., impact of wind } \\
\text { turbines on } \\
\text { birds [32], noise } \\
\text { from piling on } \\
\text { cetaceans [33] or } \\
\text { shipping } \\
\text { disturbance on a } \\
\text { variety of } \\
\text { species [34,35]. }\end{array}$ & $\begin{array}{l}\text { Certain topics/industries } \\
\text { have higher uncertainty: } \\
\text { e.g., the effect of } \\
\text { electromagnetic fields } \\
\text { (EMF) from subsea cables } \\
\text { on different life stages of } \\
\text { sensitive fish and } \\
\text { invertebrates [36,37] or } \\
\text { the effects of specific } \\
\text { chemicals like } \\
\text { polybrominated flame } \\
\text { retardants (PBFR) on } \\
\text { marine life. } \\
\text { Apply a receptor-based } \\
\text { assessment. }\end{array}$ & $\begin{array}{l}\text { Some topics have a wider } \\
\text { knowledge base than } \\
\text { others, meaning gaps in } \\
\text { our knowledge remain, } \\
\text { leading to higher } \\
\text { uncertainty in the process } \\
\text { of assessment of impacts. } \\
\text { See above for } \\
\text { receptor-based } \\
\text { assessment. }\end{array}$ & $\begin{array}{l}\text { A requirement for a more } \\
\text { mature science } \\
\text { understanding where } \\
\text { gaps remain. }\end{array}$ \\
\hline Assessment & $\begin{array}{l}\text { Research } \\
\quad \text { (data } \\
\text { available to } \\
\text { inform as- } \\
\text { sessments) }\end{array}$ & 3 & $\begin{array}{c}\text { Developers } \\
\text { undertake } \\
\text { site-specific surveys } \\
\text { on which to base } \\
\text { the EIA. }\end{array}$ & $\begin{array}{l}\text { Some developments, i.e., } \\
\text { OWFs, can take years to } \\
\text { be consented to and } \\
\text { therefore data need to be } \\
\text { updated. }\end{array}$ & $\begin{array}{l}\text { Due to length of } \\
\text { application process the } \\
\text { information provided in } \\
\text { an initial environmental } \\
\text { report (such as scoping, } \\
\text { characterisation or } \\
\text { preliminary } \\
\text { environmental } \\
\text { information report) may } \\
\text { require to be updated } \\
\text { throughout the } \\
\text { decision-making process } \\
\text { to ensure a robust } \\
\text { decision is made for } \\
\text { example site-specific } \\
\text { pre-construction surveys } \\
\text { can be requested to be } \\
\text { carried out where } \\
\text { necessary. }\end{array}$ & $\begin{array}{l}\text { Continued use of the } \\
\text { Rochdale Envelope: an } \\
\text { approach which allows } \\
\text { the developer to assess a } \\
\text { number of 'worst case } \\
\text { assessments' for large } \\
\text { projects where the EIA is } \\
\text { being carried out either } \\
\text { with years before consent } \\
\text { and construction, or in } \\
\text { cases where the } \\
\text { technology is still being } \\
\text { developed so } \\
\text { construction methods are } \\
\text { not defined [38]. }\end{array}$ \\
\hline Assessment & $\begin{array}{l}\text { Tools } \\
\text { availability }\end{array}$ & 3 & $\begin{array}{l}\text { Many tools } \\
\text { available, e.g., } \\
\text { guidelines by EC } \\
\text { and IEMA; EIA } \\
\text { checklist for } \\
\text { scoping; the Marine } \\
\text { Scotland Impact } \\
\text { Assessment Tool } \\
\text { (for wave and tidal } \\
\text { device EIA) and the } \\
\text { ODEMM approach } \\
\text { to ecological risk } \\
\text { assessment; } \\
\text { Rochdale Envelope. }\end{array}$ & $\begin{array}{l}\text { Not all tools are intuitive } \\
\text { for non-specialists. }\end{array}$ & $\begin{array}{l}\text { Tools require up-to-date } \\
\text { data to be accurate (see } \\
\text { above issue) and require } \\
\text { specialists used to } \\
\text { working with specific } \\
\text { tools or approaches to } \\
\text { undertake assessment. } \\
\text { This can be costly to the } \\
\text { developer. }\end{array}$ & $\begin{array}{l}\text { Ensure guidelines are } \\
\text { up-to-date and fit for } \\
\text { purpose. } \\
\text { Ensure tools are used } \\
\text { appropriately and by } \\
\text { properly trained experts. }\end{array}$ \\
\hline Assessment & Timeliness & 3 & $\begin{array}{c}\text { Developers } \\
\text { undertake } \\
\text { site-specific surveys } \\
\text { on which to base } \\
\text { the EIA. }\end{array}$ & $\begin{array}{l}\text { Some developments, i.e., } \\
\text { OWFs can take years to be } \\
\text { consented to and } \\
\text { therefore data need to be } \\
\text { updated to inform tools. }\end{array}$ & See assessment research. & See assessment research. \\
\hline Assessment & Confidence & 2.5 & $\begin{array}{l}\text { Tools tend to } \\
\text { specify the } \\
\text { limitations of use to } \\
\text { inform confidence } \\
\text { assessments. } \\
\text { Multiple tools } \\
\text { available for } \\
\text { diversity of marine } \\
\text { users. }\end{array}$ & $\begin{array}{l}\text { Some tools are used but } \\
\text { do not get updated with } \\
\text { newer data. }\end{array}$ & $\begin{array}{l}\text { See assessment tool } \\
\text { availability. }\end{array}$ & $\begin{array}{l}\text { See assessment tool } \\
\text { availability. }\end{array}$ \\
\hline
\end{tabular}


Table A14. Cont.

\begin{tabular}{|c|c|c|c|c|c|c|}
\hline $\begin{array}{l}\text { Thematic } \\
\text { Area }\end{array}$ & Element & Score & Rationale/Justification & $\begin{array}{l}\text { Limitations/Gaps } \\
\text { Examples }\end{array}$ & $\begin{array}{l}\text { What This Means in } \\
\text { Practice }\end{array}$ & $\begin{array}{l}\text { Recommendations for } \\
\text { Improvement }\end{array}$ \\
\hline Assessment & Use & 3 & $\begin{array}{l}\text { Tools are diverse for } \\
\text { the diversity of } \\
\text { marine users. Can } \\
\text { be combined. }\end{array}$ & $\begin{array}{c}\text { Expert judgement is often } \\
\text { applied during } \\
\text { assessment of } \\
\text { significance. }\end{array}$ & $\begin{array}{l}\text { It is often up to specialist } \\
\text { advisors, such as the } \\
\text { Cefas, to ensure that the } \\
\text { information contained } \\
\text { within an environmental } \\
\text { report is sufficient to the } \\
\text { best of their knowledge } \\
\text { and to provide additional } \\
\text { information to allow the } \\
\text { decision maker to judge } \\
\text { significance. This requires } \\
\text { that the specialists are } \\
\text { confident and competent } \\
\text { in their assessment. }\end{array}$ & $\begin{array}{c}\text { Ensure specialist } \\
\text { advisors are } \\
\text { appropriately trained } \\
\text { and senior advisors are } \\
\text { available for mentoring } \\
\text { junior colleagues. } \\
\text { Ensure decision makers } \\
\text { are appropriately trained } \\
\text { in interpreting results, } \\
\text { advice and determining } \\
\text { significance, and senior } \\
\text { colleagues are available } \\
\text { for mentoring junior } \\
\text { colleagues. }\end{array}$ \\
\hline
\end{tabular}

\begin{tabular}{llrl}
\hline Monitoring & $\begin{array}{c}\text { Data } \\
\text { availability }\end{array}$ & N/A & $\begin{array}{r}\text { This is not considered here as a separate thematic topic area as data availability is linked to monitoring } \\
\text { requirements and is site specific. Only know once you monitor what you will find. }\end{array}$ \\
\hline Monitoring & Timeliness & N/A & This is not considered here as a separate thematic topic area as it is captured under confidence/timeliness as \\
confidence is linked to timing of monitoring.
\end{tabular}

\begin{tabular}{|c|c|c|c|c|}
\hline Monitoring & $\begin{array}{c}\text { Confidence/ } \\
\text { timeliness }\end{array}$ & 3 & $\begin{array}{l}\text { Hypothesis driven } \\
\text { based on the results } \\
\text { of the EIA. Timing } \\
\text { of the monitoring is } \\
\text { determined by the } \\
\text { regulator based on } \\
\text { scientific advice and } \\
\text { results of EIS. }\end{array}$ & $\begin{array}{c}\text { Force majeure, e.g., bad } \\
\text { weather preventing } \\
\text { surveys being } \\
\text { undertaking can affect } \\
\text { how results are analysed } \\
\text { and interpreted. Difficult } \\
\text { to assess results in terms } \\
\text { of natural variation. For } \\
\text { some receptors, need a } \\
\text { long time series. }\end{array}$ \\
\hline
\end{tabular}

Monitoring Method $\quad 3 \quad \begin{gathered}\text { standards based on } \\ \text { best practice, e.g., } \\ \text { International } \\ \text { Finance } \\ \text { Corporation. }\end{gathered}$

Force majeure, e.g., bad weather preventing surveys being undertaking can affect how results are analysed and interpreted. Difficult to assess results in terms of natural variation. For some receptors, need a long time series.
Monitoring is driven by

EIA results, best practice, and expert advice. In

theory monitoring should

be 'regular' yet within guidelines for that sector/type if development.
See monitoring method and monitoring proportional.

To carry out monitoring, there are standards in place, based on best practice; however, monitoring cannot always

be enforced due to other factors having to be considered by the regulator. In addition, if the applicant carries out the monitoring with major omissions (see force majeure) or that are not appropriate for the receptor, then the data will not inform the assessment as anticipated.

The regulator can apply licensing conditions for monitoring which will be hypothesis driven aimed at addressing a specific question for that specific project. Monitoring

Force majeure, e.g., bad weather preventing surveys being undertaking can affect how results are analysed and interpreted. Difficult to assess results in terms of natural variation. For some receptors, need a long time series.
Hypothesis driven

Monitoring Proportional 4 based on the results of the EIA. conditions are also often based on prior experience from equivalent past projects. For instance, there is no need to monitor the sediment type at offshore wind farms for contaminants because the risk in these areas is low. But there is generally a need to monitor seabed changes using bathymetry to measure areas of scour around the wind turbines which could have an effect on biodiversity, but also the structural integrity of the wind turbine.
See monitoring proportional for force majeure issues.

Consider, if not already present, producing specific basic monitoring requirements for specific types of development, recognising they will have site specific differences, e.g., standard monitoring conditions.

Ensure monitoring conditions include flexibility for loss of survey data due to force majeure, e.g., regular repeatable monitoring over a long time series will allow for missing data gaps without losing

too much of the time series.

Additionally, if bad weather likely to have impacts on what monitoring (e.g., sediment composition), ensure this is taken into account in any post-weather monitoring occurring close to bad weather to account for natural variability. 
Table A14. Cont.

\begin{tabular}{|c|c|c|c|c|c|c|}
\hline $\begin{array}{l}\text { Thematic } \\
\text { Area }\end{array}$ & Element & Score & Rationale/Justification & $\begin{array}{l}\text { Limitations/Gaps } \\
\text { Examples }\end{array}$ & $\begin{array}{l}\text { What This Means in } \\
\text { Practice }\end{array}$ & $\begin{array}{l}\text { Recommendations for } \\
\text { Improvement }\end{array}$ \\
\hline Monitoring & $\begin{array}{c}\text { Use/ } \\
\text { effectiveness }\end{array}$ & $\mathrm{N} / \mathrm{A}$ & \multicolumn{4}{|c|}{$\begin{array}{l}\text { This is not considered here as a separate thematic topic area as use/effectiveness is directly linked to } \\
\text { hypothesis formed by results of EIA. }\end{array}$} \\
\hline Regulation & Specificity & 4 & $\begin{array}{l}\text { The legislative } \\
\text { drivers have been } \\
\text { specifically } \\
\text { implemented for } \\
\text { EIA, with specific } \\
\text { regulations for land } \\
\text { and sea. }\end{array}$ & $\begin{array}{l}\text { Annex II projects are open } \\
\text { to interpretation. }\end{array}$ & $\begin{array}{l}\text { Legislative drivers are } \\
\text { specific and, whilst this is } \\
\text { positive, it can mean } \\
\text { new/novel forms of } \\
\text { development get missed } \\
\text { and/or do not fit within } \\
\text { the regulations making it } \\
\text { difficult to regulate such. }\end{array}$ & $\begin{array}{l}\text { Ensure regulations are } \\
\text { regularly reviewed and } \\
\text { updated to capture } \\
\text { missed/new forms of } \\
\text { development/activity. } \\
\text { Annex II projects may be } \\
\text { open to interpretation } \\
\text { but learning from best } \\
\text { practice can help here. } \\
\text { Need to train competent } \\
\text { assessors. }\end{array}$ \\
\hline Regulation & Implementation & 4 & $\begin{array}{c}\text { Many EIA } \\
\text { practitioners } \\
\text { participate in } \\
\text { international fora, } \\
\text { such as ICES or } \\
\text { OSPAR, to apply } \\
\text { lessons learned } \\
\text { domestically. The } \\
\text { UK also has a } \\
\text { comprehensive } \\
\text { system in place to } \\
\text { implement EIA } \\
\text { regulations. }\end{array}$ & $\begin{array}{l}\text { Implementation via the } \\
\text { authoring, reviewing and } \\
\text { determination of EIAs is } \\
\text { subject largely to expert } \\
\text { judgement. }\end{array}$ & $\begin{array}{c}\text { Although heavily reliant } \\
\text { on expert judgement and } \\
\text { practices, given the wide } \\
\text { input from international } \\
\text { experts into learning and } \\
\text { implementation practices, } \\
\text { this should install a level } \\
\text { of confidence in the } \\
\text { process. }\end{array}$ & $\begin{array}{l}\text { Ensure such learning is } \\
\text { passed onto all the } \\
\text { relevant regulatory } \\
\text { bodies as not all attend } \\
\text { international fora, and } \\
\text { information is not } \\
\text { always effectively } \\
\text { communicated. }\end{array}$ \\
\hline Regulation & Timeliness & 4 & $\begin{array}{l}\text { Most of the primary } \\
\text { legislation has been } \\
\text { updated in the last } \\
\text { five years, taking } \\
\text { into account } \\
\text { developments such } \\
\text { as climate change. }\end{array}$ & $\begin{array}{l}\text { New provisions need to } \\
\text { be effectively } \\
\text { implemented and tested. }\end{array}$ & $\begin{array}{l}\text { See Regulation specificity } \\
\text { as, although they have } \\
\text { been updated, some } \\
\text { new/novel forms of } \\
\text { development may have } \\
\text { been missed. }\end{array}$ & $\begin{array}{l}\text { See Regulation } \\
\text { specificity. }\end{array}$ \\
\hline Regulation & $\begin{array}{l}\text { Monitoring/ } \\
\text { Review }\end{array}$ & 1 & $\begin{array}{l}\text { It is an obligation } \\
\text { for any changes to } \\
\text { be picked up and } \\
\text { implemented by the } \\
\text { relevant } \\
\text { departments } \\
\text { including advisory } \\
\text { bodies }\end{array}$ & $\begin{array}{l}\text { Frequency is not defined } \\
\text { but at the discretion of the } \\
\text { competent authorities and } \\
\text { usually occur due to } \\
\text { major legislative or policy } \\
\text { landscape changes. }\end{array}$ & See above. & $\begin{array}{l}\text { See Regulation specificity } \\
\text { Additionally, ensure such } \\
\text { reviews and any updates } \\
\text { these incur are passed } \\
\text { onto all the relevant } \\
\text { regulatory bodies and } \\
\text { communicated within } \\
\text { such bodies to relevant } \\
\text { parties as part of } \\
\text { updating training. }\end{array}$ \\
\hline Policy & $\begin{array}{l}\text { Evidence } \\
\text { base/data } \\
\text { availability } \\
\text { (to inform } \\
\text { policy) }\end{array}$ & 4 & $\begin{array}{l}\text { There is a long } \\
\text { history of EIA } \\
\text { (including } \\
\text { non-statutory } \\
\text { impact assessments) } \\
\text { within the UK. }\end{array}$ & $\begin{array}{l}\text { Certain topics have fewer } \\
\text { data or less timely data on } \\
\text { which to base the policy. }\end{array}$ & $\begin{array}{l}\text { The availability of } \\
\text { evidence to inform policy } \\
\text { has a general high } \\
\text { confidence, primarily due } \\
\text { to the long history of EIA } \\
\text { in the UK; however, this } \\
\text { could be tempered in light } \\
\text { of lower confidence of } \\
\text { Research overall, } \\
\text { especially with regard to } \\
\text { emerging activity and } \\
\text { development, where we } \\
\text { may not have a history of } \\
\text { impacts to learn from } \\
\text { directly. }\end{array}$ & $\begin{array}{l}\text { A requirement for a more } \\
\text { mature science } \\
\text { understanding where } \\
\text { gaps remain including at } \\
\text { the cumulative/larger } \\
\text { geographical scale. }\end{array}$ \\
\hline Policy & $\begin{array}{l}\text { Evidence/data } \\
\text { quality }\end{array}$ & $\mathrm{N} / \mathrm{A}$ & 1. & 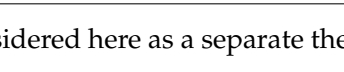 & natic topic area as it is captur & ed under Research. \\
\hline
\end{tabular}


Table A14. Cont.

\begin{tabular}{|c|c|c|c|c|c|c|}
\hline $\begin{array}{l}\text { Thematic } \\
\text { Area }\end{array}$ & Element & Score & Rationale/Justification & $\begin{array}{c}\text { Limitations/Gaps } \\
\text { Examples }\end{array}$ & $\begin{array}{l}\text { What This Means in } \\
\text { Practice }\end{array}$ & $\begin{array}{l}\text { Recommendations for } \\
\text { Improvement }\end{array}$ \\
\hline Policy & $\begin{array}{l}\text { Stakeholder/ } \\
\text { Public un- } \\
\text { derstanding }\end{array}$ & 2 & $\begin{array}{l}\text { Policies are subject } \\
\text { to public } \\
\text { consultations to } \\
\text { allow public and } \\
\text { stakeholders to } \\
\text { understand the } \\
\text { changes and feed } \\
\text { into the process. }\end{array}$ & $\begin{array}{l}\text { Level of understanding is } \\
\text { often influenced by the } \\
\text { impact on, and } \\
\text { importance of the } \\
\text { environment to, the } \\
\text { individual stakeholder in } \\
\text { question. }\end{array}$ & $\begin{array}{l}\text { It needs to be noted that } \\
\text { public understanding is } \\
\text { often linked to what is } \\
\text { 'popular' at the time, e.g., } \\
\text { a topic that will have } \\
\text { more publicly accessible } \\
\text { information available and } \\
\text { thus can be volatile but is } \\
\text { considered with scientific } \\
\text { and specialist stakeholder } \\
\text { understanding. Overall } \\
\text { low confidence in the } \\
\text { stakeholder/public } \\
\text { understanding as the } \\
\text { team's experience and } \\
\text { understanding was that } \\
\text { the level of understanding } \\
\text { is often influenced by the } \\
\text { impact on, and } \\
\text { importance of the } \\
\text { environment to, the } \\
\text { individual stakeholder in } \\
\text { question and thus is } \\
\text { difficult to measure. }\end{array}$ & $\begin{array}{l}\text { Ensure policy is balanced } \\
\text { by being informed by } \\
\text { scientific knowledge, } \\
\text { evidence, understanding, } \\
\text { best practice and } \\
\text { stakeholder/public } \\
\text { position. }\end{array}$ \\
\hline Policy & $\begin{array}{l}\text { Resource } \\
\text { allocation }\end{array}$ & $\mathrm{N} / \mathrm{A}$ & \multicolumn{4}{|c|}{$\begin{array}{l}\text { This is not considered here as a separate thematic topic area as this is dependent on the scale and type of } \\
\text { development, e.g., which statutory bodies involved. } \\
\text { N/A }\end{array}$} \\
\hline Policy & Confidence & $\mathrm{N} / \mathrm{A}$ & \multicolumn{4}{|c|}{$\begin{array}{l}\text { This is not considered here as a separate thematic topic area as it is captured under policy proportional and } \\
\text { policy evidence base. } \\
\text { N/A }\end{array}$} \\
\hline Policy & Proportional & 3.5 & $\begin{array}{l}\text { The proportionality } \\
\text { of policy drivers is } \\
\text { influenced by } \\
\text { stakeholder/public } \\
\text { understanding as } \\
\text { well as evidence. }\end{array}$ & $\begin{array}{l}\text { Level of understanding is } \\
\text { often influenced by the } \\
\text { impact on, and } \\
\text { importance of the } \\
\text { environment to, the } \\
\text { individual stakeholder in } \\
\text { question. }\end{array}$ & $\begin{array}{l}\text { See Policy } \\
\text { stakeholder/public } \\
\text { understanding. }\end{array}$ & $\begin{array}{l}\text { Ensure policy is balanced } \\
\text { by being informed by } \\
\text { scientific knowledge, } \\
\text { evidence, understanding, } \\
\text { best practice and } \\
\text { stakeholder/public } \\
\text { position. }\end{array}$ \\
\hline
\end{tabular}

Table A15. Dredge and Disposal Operations.

\begin{tabular}{|c|c|c|c|c|c|c|}
\hline $\begin{array}{l}\text { Thematic } \\
\text { Area }\end{array}$ & Element & Score & Rationale/Justification & $\begin{array}{c}\text { Limitations/Gaps } \\
\text { Examples }\end{array}$ & $\begin{array}{l}\text { What This Means in } \\
\text { Practice }\end{array}$ & $\begin{array}{l}\text { Recommendations for } \\
\text { Improvement }\end{array}$ \\
\hline Research & $\begin{array}{l}\text { Evidence } \\
\text { availability }\end{array}$ & 3.5 & $\begin{array}{l}\text { All data and } \\
\text { evidence submitted } \\
\text { are publicly } \\
\text { available. }\end{array}$ & $\begin{array}{l}\text { Some of the data are not } \\
\text { freely or easily available. }\end{array}$ & $\begin{array}{l}\text { Whilst data are freely } \\
\text { available, for people new } \\
\text { to the system, they may } \\
\text { not be able to find the } \\
\text { data easily and therefore } \\
\text { request data through } \\
\text { Environmental } \\
\text { Information Requests, } \\
\text { adding to time and } \\
\text { monetary costs. }\end{array}$ & $\begin{array}{l}\text { Having all data in an } \\
\text { easily accessible format, } \\
\text { e.g., an online portal that } \\
\text { allows interrogation or } \\
\text { interaction. Can be } \\
\text { searched through } \\
\text { multiple methods. } \\
\text { However, such a system } \\
\text { requires updating and } \\
\text { maintaining. }\end{array}$ \\
\hline Research & $\begin{array}{l}\text { Evidence } \\
\text { specificity }\end{array}$ & 3.5 & $\begin{array}{l}\text { Best practice and } \\
\text { international } \\
\text { guidelines. }\end{array}$ & $\begin{array}{l}\text { Some discrepancies, for } \\
\text { instance between } \\
\text { laboratories and experts. }\end{array}$ & $\begin{array}{l}\text { Requires a level of trust } \\
\text { between the regulator and } \\
\text { the applicant and/or } \\
\text { laboratory, which is true } \\
\text { of most application } \\
\text { systems. Follows best } \\
\text { practice but with a level of } \\
\text { pragmatism, so there are } \\
\text { some variations, e.g., } \\
\text { number of samples, based } \\
\text { on evidence and expert } \\
\text { knowledge of an area. }\end{array}$ & $\begin{array}{l}\text { Either spot checking, i.e., } \\
\text { MMO officer checking } \\
\text { sample collection, } \\
\text { laboratory methods } \\
\text { and/or monitoring of the } \\
\text { activities-however, this } \\
\text { would incur a cost. }\end{array}$ \\
\hline
\end{tabular}


Table A15. Cont.

\begin{tabular}{|c|c|c|c|c|c|c|}
\hline $\begin{array}{l}\text { Thematic } \\
\text { Area }\end{array}$ & Element & Score & Rationale/Justification & $\begin{array}{c}\text { Limitations/Gaps } \\
\text { Examples }\end{array}$ & $\begin{array}{l}\text { What This Means in } \\
\text { Practice }\end{array}$ & $\begin{array}{l}\text { Recommendations for } \\
\text { Improvement }\end{array}$ \\
\hline Research & Confidence & 3.5 & $\begin{array}{l}\text { Good } \\
\text { understanding of } \\
\text { the impacts due to } \\
\text { longevity of the } \\
\text { sector. }\end{array}$ & $\begin{array}{l}\text { Some variation amongst } \\
\text { experts and signatory } \\
\text { countries to international } \\
\text { treaties / conventions. }\end{array}$ & $\begin{array}{l}\text { There is a general } \\
\text { understanding across the } \\
\text { national experts, although } \\
\text { the remit can often drive } \\
\text { differences in advice. Will } \\
\text { consider other approaches } \\
\text { but must be led by } \\
\text { national policy and } \\
\text { precedents unless a good } \\
\text { reason not to. }\end{array}$ & $\begin{array}{l}\text { Research into the } \\
\text { longevity of impacts } \\
\text { from dredging and } \\
\text { disposal for certain areas } \\
\text { to validate advice would } \\
\text { be beneficial; however, } \\
\text { this would be research } \\
\text { and not for the purposes } \\
\text { of a licence condition. }\end{array}$ \\
\hline Research & $\begin{array}{l}\text { Evidence/ } \\
\text { knowledge } \\
\text { base }\end{array}$ & 3 & $\begin{array}{l}\text { Long history of } \\
\text { activity including } \\
\text { monitoring. Good } \\
\text { understanding of } \\
\text { the impacts. }\end{array}$ & $\begin{array}{l}\text { Proxies are used where no } \\
\text { thresholds exist, e.g., for } \\
\text { chemical analysis results. }\end{array}$ & $\begin{array}{l}\text { There is a general } \\
\text { understanding across the } \\
\text { national experts, although } \\
\text { the remit can often drive } \\
\text { differences in advice. } \\
\text { There can often be } \\
\text { differences in how experts } \\
\text { view the results of } \\
\text { contaminants where no } \\
\text { threshold exists. }\end{array}$ & $\begin{array}{l}\text { Ensuring there are } \\
\text { thresholds for all } \\
\text { contaminants where } \\
\text { possible to reduce the } \\
\text { reliance on expert } \\
\text { judgement. }\end{array}$ \\
\hline Assessment & $\begin{array}{l}\text { Research } \\
\text { (data } \\
\text { available to } \\
\text { inform as- } \\
\text { sessments) }\end{array}$ & 4 & $\begin{array}{l}\text { Good } \\
\text { understanding of } \\
\text { the impacts due to } \\
\text { longevity of the } \\
\text { sector }\end{array}$ & $\begin{array}{l}\text { Some variation amongst } \\
\text { experts and signatory } \\
\text { countries to international } \\
\text { treaties/conventions. }\end{array}$ & $\begin{array}{l}\text { There is a general } \\
\text { understanding across the } \\
\text { national experts, although } \\
\text { the remit can often drive } \\
\text { differences in advice. Will } \\
\text { consider other approaches } \\
\text { but must be led by } \\
\text { national policy and } \\
\text { precedents unless a good } \\
\text { reason not to. }\end{array}$ & $\begin{array}{l}\text { Research into the } \\
\text { longevity of impacts } \\
\text { from dredging and } \\
\text { disposal for certain areas } \\
\text { to validate advice would } \\
\text { be beneficial; however, } \\
\text { this would be research } \\
\text { and not for the purposes } \\
\text { of a licence condition. }\end{array}$ \\
\hline Assessment & $\begin{array}{l}\text { Tools } \\
\text { availability }\end{array}$ & 2 & $\begin{array}{c}\text { e.g., Mapping } \\
\text { software; OSPAR } \\
\text { Guidelines; } \\
\text { implementation of } \\
\text { thresholds. }\end{array}$ & $\begin{array}{c}\text { Requires expert } \\
\text { judgement. Thresholds } \\
\text { are not pass/fail, so open } \\
\text { to subjectivity. }\end{array}$ & $\begin{array}{l}\text { There is a general } \\
\text { understanding across the } \\
\text { national experts about the } \\
\text { approaches to use. UK } \\
\text { utilise mapping software } \\
\text { to check where samples } \\
\text { have historically been } \\
\text { taken to inform future } \\
\text { applications. There can } \\
\text { often be differences in } \\
\text { how experts view the } \\
\text { results of contaminants } \\
\text { where no threshold exists. }\end{array}$ & $\begin{array}{l}\text { Ensuring there are } \\
\text { thresholds for all } \\
\text { contaminants where } \\
\text { possible to reduce the } \\
\text { reliance on expert } \\
\text { judgement. }\end{array}$ \\
\hline Assessment & Timeliness & 4 & $\begin{array}{l}\text { OSPAR Guidelines } \\
\text { set out how often } \\
\text { sediment should be } \\
\text { analysed. }\end{array}$ & $\begin{array}{l}\text { Open to interpretation as } \\
\text { guidelines, not } \\
\text { mandatory. }\end{array}$ & $\begin{array}{c}\text { There is a general } \\
\text { understanding across the } \\
\text { national experts, although } \\
\text { the remit can often drive } \\
\text { differences in advice. Will } \\
\text { consider other approaches } \\
\text { but must be led by } \\
\text { national policy and } \\
\text { precedents unless a good } \\
\text { reason not to. }\end{array}$ & $\begin{array}{l}\text { Ensuring there are } \\
\text { thresholds for all } \\
\text { contaminants where } \\
\text { possible to reduce the } \\
\text { reliance on expert } \\
\text { judgement. Recommend } \\
\text { guidelines stay as } \\
\text { guidelines and not made } \\
\text { mandatory as one size } \\
\text { does not fit all. }\end{array}$ \\
\hline Assessment & Confidence & 3 & $\begin{array}{l}\text { Good } \\
\text { understanding of } \\
\text { the impacts due to } \\
\text { longevity of the } \\
\text { sector and access to } \\
\text { international } \\
\text { guidance. }\end{array}$ & $\begin{array}{l}\text { Relies on expert } \\
\text { judgement which can lead } \\
\text { to differing conclusions. }\end{array}$ & $\begin{array}{l}\text { There is a general } \\
\text { understanding across the } \\
\text { national experts, although } \\
\text { the remit can often drive } \\
\text { differences in advice. Will } \\
\text { consider other approaches } \\
\text { but must be led by } \\
\text { national policy and } \\
\text { precedents unless a good } \\
\text { reason not to. }\end{array}$ & $\begin{array}{l}\text { Research into the } \\
\text { longevity of impacts } \\
\text { from dredging and } \\
\text { disposal for certain areas } \\
\text { to validate advice would } \\
\text { be beneficial; however, } \\
\text { this would be research } \\
\text { and not for the purposes } \\
\text { of a licence condition. }\end{array}$ \\
\hline
\end{tabular}


Table A15. Cont.

\begin{tabular}{|c|c|c|c|c|c|c|}
\hline $\begin{array}{l}\text { Thematic } \\
\text { Area }\end{array}$ & Element & Score & Rationale/Justification & $\begin{array}{c}\text { Limitations/Gaps } \\
\text { Examples }\end{array}$ & $\begin{array}{c}\text { What This Means in } \\
\text { Practice }\end{array}$ & $\begin{array}{l}\text { Recommendations for } \\
\text { Improvement }\end{array}$ \\
\hline Assessment & Use & 2.5 & $\begin{array}{l}\text { Good } \\
\text { understanding of } \\
\text { the impacts due to } \\
\text { longevity of the } \\
\text { sector and access to } \\
\text { international } \\
\text { guidance. }\end{array}$ & $\begin{array}{l}\text { Relies on expert } \\
\text { judgement which can lead } \\
\text { to differing conclusions. } \\
\text { Tools and guidance not } \\
\text { always use by developers. }\end{array}$ & $\begin{array}{l}\text { There is a general } \\
\text { understanding across the } \\
\text { national experts, although } \\
\text { the remit can often drive } \\
\text { differences in advice. Will } \\
\text { consider other approaches } \\
\text { but must be led by } \\
\text { national policy and } \\
\text { precedents unless a good } \\
\text { reason not to. }\end{array}$ & $\begin{array}{l}\text { Research into the } \\
\text { longevity of impacts } \\
\text { from dredging and } \\
\text { disposal for certain areas } \\
\text { to validate advice would } \\
\text { be beneficial; however, } \\
\text { this would be research } \\
\text { and not for the purposes } \\
\text { of a licence condition. }\end{array}$ \\
\hline Monitoring & $\begin{array}{c}\text { Data } \\
\text { availability }\end{array}$ & 2.5 & $\begin{array}{c}\text { Results of the } \\
\text { disposal sites are } \\
\text { available publicly. }\end{array}$ & $\begin{array}{l}\text { There is no method to } \\
\text { search for disposal sites } \\
\text { that have been monitored }\end{array}$ & $\begin{array}{l}\text { Whilst data are freely } \\
\text { available, for people new } \\
\text { to the system, they may } \\
\text { not be able to find the } \\
\text { data easily and therefore } \\
\text { request data through } \\
\text { Environmental } \\
\text { Information Requests, } \\
\text { adding to time and } \\
\text { monetary costs. }\end{array}$ & $\begin{array}{l}\text { Having all data in an } \\
\text { easily accessible format, } \\
\text { e.g., an online portal that } \\
\text { allows interrogation or } \\
\text { interaction. Can be } \\
\text { searched through } \\
\text { multiple methods. } \\
\text { However, such a system } \\
\text { requires updating and } \\
\text { maintaining. }\end{array}$ \\
\hline Monitoring & Timeliness & 3 & $\begin{array}{l}\text { Monitoring } \\
\text { frequency will be a } \\
\text { licence condition. } \\
\text { The regulator-led } \\
\text { monitoring is } \\
\text { published the } \\
\text { following financial } \\
\text { year. }\end{array}$ & $\begin{array}{l}\text { There is a lag between } \\
\text { monitoring being } \\
\text { undertaken and } \\
\text { results/reports being } \\
\text { made available. }\end{array}$ & $\begin{array}{l}\text { Whilst data are freely } \\
\text { available, for people new } \\
\text { to the system, they may } \\
\text { not be able to find the } \\
\text { data easily and therefore } \\
\text { request data through } \\
\text { Environmental } \\
\text { Information Requests, } \\
\text { adding to time and } \\
\text { monetary costs. }\end{array}$ & $\begin{array}{l}\text { Having all data in an } \\
\text { easily accessible format, } \\
\text { e.g., an online portal that } \\
\text { allows interrogation or } \\
\text { interaction. Can be } \\
\text { searched through } \\
\text { multiple methods. } \\
\text { However, such a system } \\
\text { requires updating and } \\
\text { maintaining. }\end{array}$ \\
\hline Monitoring & $\begin{array}{l}\text { Confidence/ } \\
\text { timeliness }\end{array}$ & 3.5 & $\begin{array}{c}\text { There are } \\
\text { international } \\
\text { standards and best } \\
\text { practices that are } \\
\text { routinely applied, } \\
\text { as well as standards } \\
\text { for sample analysis, } \\
\text { e.g., MMO. } \\
\text { Monitoring and } \\
\text { reporting frequency } \\
\text { will be a licence } \\
\text { condition. }\end{array}$ & $\begin{array}{l}\text { There are differences } \\
\text { between laboratories for } \\
\text { chemical analysis which } \\
\text { may result in different } \\
\text { values being reported. }\end{array}$ & $\begin{array}{l}\text { Requires a level of trust } \\
\text { between the regulator and } \\
\text { the applicant and/or } \\
\text { laboratory, which is true } \\
\text { of most application } \\
\text { systems. Follows best } \\
\text { practice but with a level of } \\
\text { pragmatism so there are } \\
\text { some variations, e.g., } \\
\text { number of samples, based } \\
\text { on evidence and expert } \\
\text { knowledge of an area. }\end{array}$ & $\begin{array}{l}\text { Either spot checking, i.e., } \\
\text { MMO officer checking } \\
\text { sample collection, } \\
\text { laboratory methods } \\
\text { and/or monitoring of the } \\
\text { activities-however, this } \\
\text { would incur a cost. }\end{array}$ \\
\hline Monitoring & Method & 3 & $\begin{array}{c}\text { There are } \\
\text { international } \\
\text { standards and best } \\
\text { practices that are } \\
\text { routinely applied, } \\
\text { as well as standards } \\
\text { for sample analysis, } \\
\text { e.g., MMO. }\end{array}$ & $\begin{array}{l}\text { There are differences } \\
\text { between laboratories for } \\
\text { chemical analysis which } \\
\text { may result in different } \\
\text { values being reported. }\end{array}$ & $\begin{array}{l}\text { Requires a level of trust } \\
\text { between the regulator and } \\
\text { the applicant and/or } \\
\text { laboratory, which is true } \\
\text { of most application } \\
\text { systems. Follows best } \\
\text { practice but with a level of } \\
\text { pragmatism so there are } \\
\text { some variations, e.g., } \\
\text { number of samples, based } \\
\text { on evidence and expert } \\
\text { knowledge of an area. }\end{array}$ & $\begin{array}{l}\text { Either spot checking, i.e., } \\
\text { MMO officer checking } \\
\text { sample collection, } \\
\text { laboratory methods } \\
\text { and/or monitoring of the } \\
\text { activities-however, this } \\
\text { would incur a cost. }\end{array}$ \\
\hline Monitoring & Proportional & 3.5 & $\begin{array}{l}\text { Hypothesis driven } \\
\text { based on the results } \\
\text { of the assessment. }\end{array}$ & $\begin{array}{l}\text { Force majeure, e.g., bad } \\
\text { weather preventing } \\
\text { surveys being } \\
\text { undertaking can affect } \\
\text { how results are analysed } \\
\text { and interpreted. Difficult } \\
\text { to assess results in terms } \\
\text { of natural variation. For } \\
\text { some receptors, need a } \\
\text { long time series. }\end{array}$ & $\begin{array}{l}\text { Monitoring to determine } \\
\text { impacts in the context of } \\
\text { background variation is } \\
\text { difficult to ascertain yet } \\
\text { decisions still need to be } \\
\text { made as to whether the } \\
\text { monitoring and/or } \\
\text { activity should be allowed } \\
\text { to continue (either as is, or } \\
\text { with mitigation measures). } \\
\text { Requiring additional time } \\
\text { series data but being } \\
\text { bound by the licence. }\end{array}$ & $\begin{array}{l}\text { Ensure monitoring is } \\
\text { continued for as long as } \\
\text { required, i.e., ensure } \\
\text { marine licence condition } \\
\text { is hypothesis driven and } \\
\text { not time bound in the } \\
\text { first instance. }\end{array}$ \\
\hline
\end{tabular}


Table A15. Cont.

\begin{tabular}{|c|c|c|c|c|c|c|}
\hline $\begin{array}{l}\text { Thematic } \\
\text { Area }\end{array}$ & Element & Score & Rationale/Justification & $\begin{array}{c}\text { Limitations/Gaps } \\
\text { Examples }\end{array}$ & $\begin{array}{l}\text { What This Means in } \\
\text { Practice }\end{array}$ & $\begin{array}{l}\text { Recommendations for } \\
\text { Improvement }\end{array}$ \\
\hline Regulation & Specificity & 2.5 & $\begin{array}{l}\text { Specific provisions for } \\
\text { dredge and disposal } \\
\text { operations. Specific } \\
\text { international guidance, } \\
\text { e.g., OSPAR, 2014. }\end{array}$ & $\begin{array}{l}\text { The regulations were } \\
\text { not developed } \\
\text { specifically for the } \\
\text { management of dredge } \\
\text { and disposal operations. }\end{array}$ & $\begin{array}{l}\text { Often developers have } \\
\text { to consult multiple } \\
\text { legislative texts (MCAA, } \\
\text { OSPAR, LCLP) as well } \\
\text { as previous applications } \\
\text { to ensure following } \\
\text { mandatory and } \\
\text { recommended texts, as } \\
\text { well as applying } \\
\text { consistently and any } \\
\text { variation is (still legal) } \\
\text { based on sound } \\
\text { evidence. }\end{array}$ & $\begin{array}{l}\text { None } \\
\text { recommended-the } \\
\text { regulations are updated } \\
\text { to reflect changes in } \\
\text { methods and science. } \\
\text { International treaties are } \\
\text { clear. Recommend } \\
\text { guidelines stay as } \\
\text { guidelines and not made } \\
\text { mandatory as one size } \\
\text { does not fit all. }\end{array}$ \\
\hline
\end{tabular}

\begin{tabular}{|c|c|c|c|c|c|c|}
\hline Regulation & Implementation & 4 & $\begin{array}{c}\text { The Marine and Coastal } \\
\text { Access Act has now } \\
\text { been implemented for } \\
\text { over ten years and } \\
\text { based on previous } \\
\text { regulations and } \\
\text { therefore } \\
\text { well-established across } \\
\text { a multitude of activities } \\
\text { and developments. }\end{array}$ & $\begin{array}{c}\text { No major weaknesses } \\
\text { identified. }\end{array}$ & $\begin{array}{l}\text { For standard dredge } \\
\text { and disposals, MCAA is } \\
\text { now well known } \\
\text { amongst its regular } \\
\text { users. For less routine, } \\
\text { e.g., accelerated } \\
\text { dredges, the exemptions } \\
\text { and guidance are } \\
\text { available online. }\end{array}$ & $\begin{array}{c}\text { No major weaknesses } \\
\text { identified. }\end{array}$ \\
\hline Regulation & Timeliness & 4 & $\begin{array}{l}\text { The Marine and Coastal } \\
\text { Access Act has recently } \\
\text { been updated } 2019 \text { to } \\
\text { refine the activities } \\
\text { exempt from requiring a } \\
\text { marine licence. }\end{array}$ & $\begin{array}{l}\text { New provisions need to } \\
\text { be effectively } \\
\text { implemented and } \\
\text { tested. }\end{array}$ & $\begin{array}{l}\text { For standard dredge } \\
\text { and disposals, MCAA is } \\
\text { now well known } \\
\text { amongst its regular } \\
\text { users. For less routine, } \\
\text { e.g., accelerated } \\
\text { dredges, the exemptions } \\
\text { and guidance are } \\
\text { available online. }\end{array}$ & $\begin{array}{l}\text { No major weaknesses } \\
\text { identified. New } \\
\text { provisions need to be } \\
\text { effectively implemented } \\
\text { and tested. }\end{array}$ \\
\hline Regulation & $\begin{array}{l}\text { Monitoring/ } \\
\text { Review }\end{array}$ & 1 & $\begin{array}{l}\text { It is an obligation for } \\
\text { any changes to be } \\
\text { picked up and } \\
\text { implemented by the } \\
\text { relevant departments } \\
\text { including advisory } \\
\text { bodies. }\end{array}$ & $\begin{array}{c}\text { Frequency is not } \\
\text { defined but at the } \\
\text { discretion of the } \\
\text { competent authorities } \\
\text { and usually occur due } \\
\text { to major legislative or } \\
\text { policy landscape } \\
\text { changes. }\end{array}$ & $\begin{array}{l}\text { Due to the time and cost } \\
\text { of updating regulations, } \\
\text { this tends to be carried } \\
\text { out when there is a } \\
\text { major shift in } \\
\text { understanding, e.g., the } \\
\text { implementation of the } \\
\text { exemptions and } \\
\text { amendments for } \\
\text { agitation dredging. } \\
\text { Smaller discrepancies } \\
\text { may be put 'on hold'. }\end{array}$ & $\begin{array}{l}\text { None } \\
\text { recommended-the } \\
\text { regulations are updated } \\
\text { to reflect changes in } \\
\text { methods and science. } \\
\text { International treaties are } \\
\text { clear. Recommend } \\
\text { guidelines stay as } \\
\text { guidelines and not made } \\
\text { mandatory as one size } \\
\text { does not fit all. New } \\
\text { provisions need to be } \\
\text { effectively implemented } \\
\text { and tested. }\end{array}$ \\
\hline Policy & $\begin{array}{l}\text { Evidence } \\
\text { base/data } \\
\text { availability } \\
\text { (to inform } \\
\text { policy) }\end{array}$ & 4 & $\begin{array}{l}\text { Evidence collection and } \\
\text { assessment follow the } \\
\text { international guidance, } \\
\text { and all data are publicly } \\
\text { available. }\end{array}$ & $\begin{array}{l}\text { Regulators should } \\
\text { consider advancements } \\
\text { in scientific field, but it } \\
\text { is recognised that } \\
\text { amending criteria for } \\
\text { methods or thresholds } \\
\text { could have } \\
\text { socio-economic } \\
\text { implications which } \\
\text { should be balanced. }\end{array}$ & $\begin{array}{l}\text { Advancements can take } \\
\text { time to come online as } \\
\text { impact assessments } \\
\text { must be undertaken, as } \\
\text { well as challenging the } \\
\text { legality of changes } \\
\text { (does it change our } \\
\text { position legally) and the } \\
\text { robustness of evidence } \\
\text { (does the change make a } \\
\text { marked step forward in } \\
\text { terms of evidence } \\
\text { confidence?). }\end{array}$ & $\begin{array}{l}\text { No major weaknesses } \\
\text { identified. Where gaps } \\
\text { are identified and } \\
\text { considered a priority, } \\
\text { funding can be made } \\
\text { available to investigate } \\
\text { how to implement. }\end{array}$ \\
\hline Policy & $\begin{array}{l}\text { Evidence/data } \\
\text { quality }\end{array}$ & & \multicolumn{4}{|c|}{ This is the same for evidence base for this sector. } \\
\hline
\end{tabular}


Table A15. Cont.

\begin{tabular}{|c|c|c|c|c|c|c|}
\hline $\begin{array}{c}\text { Thematic } \\
\text { Area }\end{array}$ & Element & Score & Rationale/Justification & $\begin{array}{c}\text { Limitations/Gaps } \\
\text { Examples }\end{array}$ & $\begin{array}{c}\text { What This Means in } \\
\text { Practice }\end{array}$ & $\begin{array}{l}\text { Recommendations for } \\
\text { Improvement }\end{array}$ \\
\hline Policy & $\begin{array}{l}\text { Stakeholder/ } \\
\text { Public un- } \\
\text { derstanding }\end{array}$ & 2 & $\begin{array}{l}\text { Policies are subject } \\
\text { to public } \\
\text { consultations to } \\
\text { allow public and } \\
\text { stakeholders to } \\
\text { understand the } \\
\text { changes and feed } \\
\text { into the process. }\end{array}$ & $\begin{array}{l}\text { Limited understanding of } \\
\text { the specific needs, } \\
\text { assessments, requirements } \\
\text { or how these are driven } \\
\text { by the policies and social } \\
\text { science brings this } \\
\text { additional information on } \\
\text { human behaviour to the } \\
\text { fore. }\end{array}$ & $\begin{array}{l}\text { There are no specific } \\
\text { policies for dredge and } \\
\text { disposal operations in } \\
\text { terms of navigation (some } \\
\text { are embedded in terms of } \\
\text { flood management). } \\
\text { Approach is driven by } \\
\text { national legislation and } \\
\text { international treaties, as } \\
\text { well as guidance. Public } \\
\text { involvement tends to be } \\
\text { for issues such as flooding } \\
\text { or high-profile cases such } \\
\text { as Hinkley. }\end{array}$ & $\begin{array}{l}\text { No major weaknesses } \\
\text { identified. Policy makers } \\
\text { and regulators may want } \\
\text { to consider having public } \\
\text { documents which } \\
\text { explain the process for } \\
\text { answering EIRs as } \\
\text { individual responses can } \\
\text { be time consuming. }\end{array}$ \\
\hline Policy & $\begin{array}{l}\text { Resource } \\
\text { allocation }\end{array}$ & 2.5 & $\begin{array}{l}\text { There is currently } \\
\text { sufficient resource } \\
\text { within the } \\
\text { organisations to } \\
\text { continue the status } \\
\text { quo. }\end{array}$ & $\begin{array}{l}\text { Recognised lag between } \\
\text { high case work and being } \\
\text { able to employ further } \\
\text { resource leading to a } \\
\text { temporary period of } \\
\text { constraint working. }\end{array}$ & $\begin{array}{l}\text { Generally, all work is } \\
\text { completed to set timelines, } \\
\text { regardless of resource } \\
\text { availability. Recognised } \\
\text { that new colleagues in all } \\
\text { organisations require } \\
\text { some level of support. }\end{array}$ & $\begin{array}{c}\text { No major weaknesses } \\
\text { identified. }\end{array}$ \\
\hline Policy & Confidence & \multicolumn{5}{|c|}{ This is the same for evidence base for this sector. } \\
\hline Policy & Proportional & 4 & $\begin{array}{l}\text { Regulators often } \\
\text { utilise the expertise } \\
\text { of their (statutory } \\
\text { and non-statutory) } \\
\text { scientific advisors, } \\
\text { such as the Cefas, } \\
\text { utilising corporate } \\
\text { knowledge to } \\
\text { ensure } \\
\text { proportionality. }\end{array}$ & $\begin{array}{l}\text { Relies on either } \\
\text { long-standing members of } \\
\text { an organisation or } \\
\text { effective succession } \\
\text { planning and filing to } \\
\text { ensure consistency. }\end{array}$ & $\begin{array}{l}\text { The employment of } \\
\text { document storage } \\
\text { systems, mapping tools } \\
\text { and databases to allow } \\
\text { colleagues to 'take over' } \\
\text { when needed and take } \\
\text { into consideration } \\
\text { previous advice. }\end{array}$ & $\begin{array}{l}\text { No major weaknesses } \\
\text { identified. Would benefit } \\
\text { from having all data in } \\
\text { an easily accessible } \\
\text { format, e.g., an online } \\
\text { portal that allows } \\
\text { interrogation or } \\
\text { interaction. Can be } \\
\text { searched through } \\
\text { multiple methods. } \\
\text { However, such a system } \\
\text { requires updating and } \\
\text { maintaining. }\end{array}$ \\
\hline
\end{tabular}

Table A16. Marine Protected Areas.

\begin{tabular}{|c|c|c|c|c|c|c|}
\hline $\begin{array}{c}\text { Thematic } \\
\text { Area }\end{array}$ & Element & Score & Rationale/Justification & $\begin{array}{c}\text { Limitations/Gaps } \\
\text { Examples }\end{array}$ & $\begin{array}{l}\text { What This Means in } \\
\text { Practice }\end{array}$ & $\begin{array}{l}\text { Recommendations for } \\
\text { Improvement }\end{array}$ \\
\hline Research & $\begin{array}{l}\text { Evidence } \\
\text { availability }\end{array}$ & 2.5 & $\begin{array}{l}\text { There are several } \\
\text { studies that have } \\
\text { been undertaken } \\
\text { internationally. }\end{array}$ & $\begin{array}{l}\text { Data underpinning } \\
\text { these studies are often } \\
\text { not released as they are } \\
\text { being analysed for } \\
\text { research purposes. }\end{array}$ & $\begin{array}{l}\text { That some data are made } \\
\text { available for other studies, } \\
\text { although even freely } \\
\text { available data are not } \\
\text { available for some time } \\
\text { and may not be aware the } \\
\text { data are available unless } \\
\text { known, can limit studies. }\end{array}$ & $\begin{array}{l}\text { All research data should be } \\
\text { stored on public databases } \\
\text { to aid access. Database } \\
\text { access should be user } \\
\text { developed rather than } \\
\text { holder developed to avoid } \\
\text { unnecessarily complex } \\
\text { download process. }\end{array}$ \\
\hline Research & $\begin{array}{l}\text { Evidence } \\
\text { specificity }\end{array}$ & 2 & $\begin{array}{c}\text { Research } \\
\text { undertaken to } \\
\text { answer specific } \\
\text { questions or gaps. }\end{array}$ & $\begin{array}{l}\text { The quality is variable } \\
\text { and misses key } \\
\text { elements required for } \\
\text { designation. }\end{array}$ & $\begin{array}{l}\text { Data are available, but } \\
\text { often at considerable cost } \\
\text { in terms of time or fees } \\
\text { which means others } \\
\text { cannot easily use to } \\
\text { inform their own } \\
\text { assessments. }\end{array}$ & $\begin{array}{l}\text { All research data should be } \\
\text { stored on public databases } \\
\text { to aid access. Database } \\
\text { access should be user } \\
\text { developed rather than } \\
\text { holder developed to avoid } \\
\text { unnecessarily complex } \\
\text { download process. }\end{array}$ \\
\hline Research & Confidence & 2.5 & $\begin{array}{l}\text { Some programmes } \\
\text { are specific and } \\
\text { undertaken using } \\
\text { international } \\
\text { methods. }\end{array}$ & $\begin{array}{l}\text { Other studies rely on } \\
\text { stakeholder input. }\end{array}$ & $\begin{array}{l}\text { The reliance on } \\
\text { stakeholder input allows } \\
\text { for additional information } \\
\text { which may not otherwise } \\
\text { be collected and the } \\
\text { proposals generally more } \\
\text { accepted if the public feel } \\
\text { they contributed and own } \\
\text { the decision, but } \\
\text { stakeholder data often has } \\
\text { lower confidence than } \\
\text { empirical data. }\end{array}$ & $\begin{array}{l}\text { Research into how current } \\
\text { data can be pulled together, } \\
\text { but also going forward, } \\
\text { standard data } \\
\text { requirements set by } \\
\text { regulators to aid in } \\
\text { comparability and carrying } \\
\text { out ecosystem-level } \\
\text { assessments. }\end{array}$ \\
\hline
\end{tabular}


Table A16. Cont.

\begin{tabular}{|c|c|c|c|c|c|c|}
\hline $\begin{array}{l}\text { Thematic } \\
\text { Area }\end{array}$ & Element & Score & Rationale/Justification & $\begin{array}{l}\text { Limitations/Gaps } \\
\text { Examples }\end{array}$ & $\begin{array}{l}\text { What This Means in } \\
\text { Practice }\end{array}$ & $\begin{array}{l}\text { Recommendations for } \\
\text { Improvement }\end{array}$ \\
\hline Research & $\begin{array}{l}\text { Evidence/ } \\
\text { knowledge } \\
\text { base }\end{array}$ & 2.5 & $\begin{array}{c}\text { Extensive studies } \\
\text { have been } \\
\text { undertaken } \\
\text { internationally. }\end{array}$ & $\begin{array}{l}\text { Fewer studies have } \\
\text { been carried out on } \\
\text { UK-specific MPAs. }\end{array}$ & $\begin{array}{l}\text { Confidence in the } \\
\text { individual studies is good. } \\
\text { However, extrapolation to } \\
\text { UK ecosystem-level } \\
\text { effects is very limited. }\end{array}$ & $\begin{array}{l}\text { Research into how current } \\
\text { data can be pulled together, } \\
\text { but also going forward, } \\
\text { standard data } \\
\text { requirements set by } \\
\text { regulators to aid in } \\
\text { comparability and carrying } \\
\text { out ecosystem-level } \\
\text { assessments. }\end{array}$ \\
\hline
\end{tabular}

\begin{tabular}{cc}
\hline Assessment & $\begin{array}{c}\text { Research } \\
\text { (data } \\
\text { available to } \\
\text { inform as- } \\
\text { sessments) }\end{array}$ \\
\hline Assessment & $\begin{array}{c}\text { Tools } \\
\text { availability }\end{array}$ \\
\hline Assessment & Timeliness \\
\hline Assessment & Confidence \\
\hline Assessment & Use
\end{tabular}

Monitoring $\begin{gathered}\text { Data } \\ \text { availability } \quad 1.5 \quad \begin{array}{c}\text { There are a number } \\ \text { of studies that have } \\ \text { been undertaken } \\ \text { internationally. }\end{array}\end{gathered} \begin{gathered}\begin{array}{c}\text { Data underpinning } \\ \text { these studies are often } \\ \text { not released as they are } \\ \text { being analysed for } \\ \text { research purposes }\end{array}\end{gathered}$

Data are available, but often at considerable cost in terms of time or fees which means others cannot easily use to inform their own assessments.
All research data should be stored on public databases to aid access. Database access should be user developed rather than

holder developed to avoid unnecessarily complex download process.

\begin{tabular}{|c|c|c|c|c|c|c|}
\hline Monitoring & Timeliness & \multicolumn{5}{|c|}{ This is not considered as a separate thematic topic area as this is covered under (Monitoring) confidence/timeliness. } \\
\hline Monitoring & $\begin{array}{c}\text { Confidence/ } \\
\text { timeliness }\end{array}$ & 2 & $\begin{array}{l}\text { Some programmes } \\
\text { are specific and } \\
\text { undertaken using } \\
\text { international } \\
\text { methods. }\end{array}$ & $\begin{array}{l}\text { Other studies rely on } \\
\text { stakeholder input } \\
\text { which can have lower } \\
\text { confidence or data are } \\
\text { limited. }\end{array}$ & $\begin{array}{l}\text { Confidence in the } \\
\text { individual studies is good. } \\
\text { However, extrapolation to } \\
\text { ecosystem-level effects is } \\
\text { very limited. }\end{array}$ & $\begin{array}{l}\text { Research into how current } \\
\text { data can be pulled together, } \\
\text { but also going forward, } \\
\text { standard data } \\
\text { requirements set by } \\
\text { regulators to aid in } \\
\text { comparability and carrying } \\
\text { out ecosystem-level } \\
\text { assessments. }\end{array}$ \\
\hline Monitoring & Method & 2 & $\begin{array}{c}\text { Defined processes } \\
\text { for designating } \\
\text { MPAs. }\end{array}$ & $\begin{array}{l}\text { Due to limitations of } \\
\text { some data, a } \\
\text { precautionary approach } \\
\text { can be taken. Some } \\
\text { gaps in knowledge. }\end{array}$ & $\begin{array}{c}\text { Some MPAs require } \\
\text { additional monitoring } \\
\text { following designation to } \\
\text { fill some of the gaps and } \\
\text { inform the assessment for } \\
\text { meeting favourable } \\
\text { condition. }\end{array}$ & $\begin{array}{c}\text { There is little improvement } \\
\text { that can be done given } \\
\text { statutory timelines for } \\
\text { designating national } \\
\text { MPAs. }\end{array}$ \\
\hline Monitoring & Proportional & 2 & $\begin{array}{l}\text { Management } \\
\text { measures assessed } \\
\text { at the designation } \\
\text { stage. Over } 120 \\
\text { byelaws have been } \\
\text { introduced. }\end{array}$ & $\begin{array}{l}\text { Some uncertainty exists } \\
\text { which can lead to } \\
\text { precautionary } \\
\text { approaches being } \\
\text { applied. }\end{array}$ & $\begin{array}{c}\text { Some MPAs require } \\
\text { additional monitoring } \\
\text { following designation to } \\
\text { fill some of the gaps and } \\
\text { inform the assessment for } \\
\text { meeting favourable } \\
\text { condition. }\end{array}$ & $\begin{array}{c}\text { There is little improvement } \\
\text { that can be done given } \\
\text { statutory timelines for } \\
\text { designating national } \\
\text { MPAs. }\end{array}$ \\
\hline Monitoring & $\begin{array}{c}\text { Use/ } \\
\text { effectiveness }\end{array}$ & 1.5 & $\begin{array}{l}\text { Over } 120 \text { byelaws } \\
\text { have been } \\
\text { introduced. } \\
\text { Monitoring } \\
\text { programme in } \\
\text { place. }\end{array}$ & $\begin{array}{l}\text { No assessment has been } \\
\text { undertaken on the } \\
\text { effectiveness of } \\
\text { management measures. } \\
\text { Monitoring programme } \\
\text { in early stages. }\end{array}$ & $\begin{array}{l}\text { Due to the early stages of } \\
\text { the management } \\
\text { measures, there is little } \\
\text { information regarding } \\
\text { their effectiveness in situ. } \\
\text { Changing conditions may } \\
\text { also require a change } \\
\text { measure which may not } \\
\text { easily be identified or } \\
\text { implemented. }\end{array}$ & $\begin{array}{c}\text { There is little improvement } \\
\text { at this stage given the early } \\
\text { stages of the monitoring } \\
\text { programme, but } \\
\text { monitoring should be } \\
\text { hypothesis driven and } \\
\text { linked to conservation } \\
\text { objectives/management } \\
\text { measures. }\end{array}$ \\
\hline
\end{tabular}


Table A16. Cont.

\begin{tabular}{|c|c|c|c|c|c|c|}
\hline $\begin{array}{l}\text { Thematic } \\
\text { Area }\end{array}$ & Element & Score & Rationale/Justification & $\begin{array}{c}\text { Limitations/Gaps } \\
\text { Examples }\end{array}$ & $\begin{array}{l}\text { What This Means in } \\
\text { Practice }\end{array}$ & $\begin{array}{l}\text { Recommendations for } \\
\text { Improvement }\end{array}$ \\
\hline Regulation & Specificity & 4 & $\begin{array}{l}\text { National regulations are } \\
\text { not specifically for the } \\
\text { designation of MPAs } \\
\text { but provide a strong } \\
\text { statutory requirement. } \\
\text { International directives } \\
\text { specific for MPAS. }\end{array}$ & $\begin{array}{l}\text { The national regulations } \\
\text { were not developed } \\
\text { specifically for the } \\
\text { designation of MPAs. }\end{array}$ & $\begin{array}{l}\text { Often have to consult } \\
\text { multiple legislative } \\
\text { texts (MCAA, TCPA, } \\
\text { Directives) to ensure } \\
\text { following mandatory } \\
\text { and recommended texts, } \\
\text { as well as applying } \\
\text { consistently and any } \\
\text { variation is (still legal) } \\
\text { based on sound } \\
\text { evidence. }\end{array}$ & $\begin{array}{l}\text { None } \\
\text { recommended-the } \\
\text { regulations are updated } \\
\text { to reflect changes in } \\
\text { methods and science. } \\
\text { International treaties are } \\
\text { clear. Recommend } \\
\text { guidelines stay as } \\
\text { guidelines and not made } \\
\text { mandatory as one size } \\
\text { does not fit all. }\end{array}$ \\
\hline
\end{tabular}

The EU Directives have resulted in $933 \mathrm{MPAs}$ and The Town and Country Planning Act

has been implemented since 1990 and has resulted in 4126 SSSIs (including terrestrial).

Regulation Implementation $4 \quad \begin{gathered}\text { Under the MCAA, the } \\ \text { UK in } 2019 \text { fully } \\ \text { implemented the MCZ }\end{gathered}$

Regulation Implementation $4 \quad \begin{gathered}\text { Under the MCAA, the } \\ \text { UK in } 2019 \text { fully } \\ \text { implemented the MCZ }\end{gathered}$ network and has worked to create an ecologically coherent network which is deemed sufficiently complete.
MPAs under all legislation has been implemented, with some having been monitored and assessed against baselines.
None recommended.

The regulations have

been successfully implemented.

\section{regulations.}

There is an international ambition to increase marine protected areas and the combination of the regulations set out how to meet requirement.
Some of regulations are over 30 years old.
Whilst some regulations are old, they have been updated and guidelines updated to reflect evolving knowledge.
For MCZs, there is a statutory requirement to

Regulation Monitoring/ 2.5

For

For European sites,

there is a requirement to monitor.
The large number of sites and features designated require large resources to monitor effectively.
Due to the early stages of the management measures, there is little information regarding their effectiveness in situ. Changing conditions may also require a change measure which may not easily be identified or implemented.

That some data are made available for other studies, although even freely available data are not available for some time and may not be aware the data are available unless known, can limit studies.
The data behind these base/data

Policy (to inform policy) designations are
available.
Data need to be requested for use.
Data are available, but often at considerable cost in terms of time or fees which means others

cannot easily use to

inform their own assessments.

\section{None}

recommended-the regulations are updated to reflect changes in methods and science.

International treaties are

clear. Recommend guidelines stay as guidelines and not made mandatory as one size does not fit all.

There is little improvement at this stage given the early stages of the monitoring programme, but monitoring should be hypothesis driven and linked to conservation objectives/management measures.

All research data should be stored on public

databases to aid access. Database access should be user developed rather than holder developed to avoid unnecessarily complex download process.

All research data should be stored on public databases to aid access. Database access should be user developed rather than holder developed to avoid unnecessarily complex download process. 
Table A16. Cont.

\begin{tabular}{|c|c|c|c|c|c|c|}
\hline $\begin{array}{l}\text { Thematic } \\
\text { Area }\end{array}$ & Element & Score & Rationale/Justification & $\begin{array}{c}\text { Limitations/Gaps } \\
\text { Examples }\end{array}$ & $\begin{array}{l}\text { What This Means in } \\
\text { Practice }\end{array}$ & $\begin{array}{l}\text { Recommendations for } \\
\text { Improvement }\end{array}$ \\
\hline Policy & $\begin{array}{l}\text { Stakeholder/ } \\
\text { Public un- } \\
\text { derstanding }\end{array}$ & 2.5 & $\begin{array}{l}\text { There has been } \\
\text { increased publicity in } \\
\text { the marine environment } \\
\text { through political } \\
\text { agendas but also due to } \\
\text { advocates such as } \\
\text { David Attenborough. } \\
\text { MCZs were originally } \\
\text { designed to be 'bottom } \\
\text { up' with stakeholders. }\end{array}$ & $\begin{array}{l}\text { There are different } \\
\text { levels of knowledge, } \\
\text { understanding and } \\
\text { engagement. }\end{array}$ & $\begin{array}{l}\text { Some of the public are } \\
\text { for or against, and much } \\
\text { depends on livelihood, } \\
\text { i.e., fishermen do not } \\
\text { want to be affected by } \\
\text { management measures } \\
\text { in the MPAs. Some of } \\
\text { this is due to the early } \\
\text { stages of national MPAs } \\
\text { and management } \\
\text { measures. }\end{array}$ & $\begin{array}{l}\text { Education of the public } \\
\text { on marine management } \\
\text { as a whole as there is no } \\
\text { one approach to } \\
\text { management, nor one } \\
\text { solution. }\end{array}$ \\
\hline Policy & $\begin{array}{l}\text { Resource } \\
\text { allocation }\end{array}$ & \multicolumn{5}{|c|}{$\begin{array}{l}\text { This is not considered due to the wide-ranging input from different agencies into the designation and management of } \\
\text { MPAs. }\end{array}$} \\
\hline Policy & Confidence & \multicolumn{5}{|c|}{$\begin{array}{c}\text { This is not considered as a separate thematic topic area as this is covered under (Policy) for evidence base and } \\
\text { evidence quality, as well as research and monitoring. }\end{array}$} \\
\hline Policy & Proportional & 3.5 & $\begin{array}{c}\text { The policies around the } \\
\text { designation of MCZs } \\
\text { were based on a } \\
\text { balanced approach of } \\
\text { available } \\
\text { science/evidence/data, } \\
\text { uncertainty, and the } \\
\text { economic impact. }\end{array}$ & $\begin{array}{l}\text { Some uncertainties } \\
\text { regarding management } \\
\text { measures leading to } \\
\text { precautionary } \\
\text { approaches being } \\
\text { applied. }\end{array}$ & $\begin{array}{l}\text { Some MPAs require } \\
\text { additional monitoring } \\
\text { following designation } \\
\text { to fill some of the gaps } \\
\text { and inform the } \\
\text { assessment for meeting } \\
\text { favourable condition. }\end{array}$ & $\begin{array}{l}\text { There is little } \\
\text { improvement that can be } \\
\text { done given statutory } \\
\text { timelines for designating } \\
\text { national MPAs. }\end{array}$ \\
\hline
\end{tabular}

Table A17. Offshore Renewable Energy Developments.

\begin{tabular}{|c|c|c|c|c|c|c|}
\hline $\begin{array}{l}\text { Thematic } \\
\text { Area }\end{array}$ & Element & Score & Rationale/Justification & $\begin{array}{c}\text { Limitations/Gaps } \\
\text { Examples }\end{array}$ & $\begin{array}{l}\text { What This Means in } \\
\text { Practice }\end{array}$ & $\begin{array}{l}\text { Recommendations for } \\
\text { Improvement }\end{array}$ \\
\hline Research & $\begin{array}{l}\text { Evidence } \\
\text { availability }\end{array}$ & 1.5 & $\begin{array}{c}\text { Academic and } \\
\text { government research } \\
\text { data are well publicised } \\
\text { and published. } \\
\text { Databases such as the } \\
\text { Tethys Environmental } \\
\text { Effects of Wind and } \\
\text { Marine Renewable } \\
\text { Energy have helped } \\
\text { reduce the effort } \\
\text { required to find } \\
\text { information. } \\
\text { Coordinated } \\
\text { programmes such as } \\
\text { Collaborative Offshore } \\
\text { Windfarm Research Into } \\
\text { the Environment } \\
\text { (COWRIE), ORJIP and } \\
\text { <Belgium OWF research, } \\
\text { WREN/Annex } 4 \text {. } \\
\text { There are a number of } \\
\text { studies that have been } \\
\text { undertaken } \\
\text { internationally. }\end{array}$ & $\begin{array}{l}\text { Many datasets require } \\
\text { personal requests for } \\
\text { the data rather than } \\
\text { being directly } \\
\text { downloadable. } \\
\text { Developer data such as } \\
\text { details of devices, } \\
\text { installation methods, } \\
\text { timings are often not } \\
\text { available. } \\
\text { Industry data may also } \\
\text { be behind subscription } \\
\text { or membership services } \\
\text { (e.g., } 4 \text { COffshore or } \\
\text { RenewableUK). These } \\
\text { services are often } \\
\text { prohibitively expensive } \\
\text { to academic and } \\
\text { government } \\
\text { researchers. }\end{array}$ & $\begin{array}{l}\text { Data are available, but } \\
\text { often at considerable } \\
\text { cost in terms of time or } \\
\text { fees which means others } \\
\text { cannot easily use to } \\
\text { inform their own } \\
\text { assessments. }\end{array}$ & $\begin{array}{c}\text { All research data should } \\
\text { be stored on public } \\
\text { databases to aid access. } \\
\text { Database access should } \\
\text { be user developed rather } \\
\text { than holder developed to } \\
\text { avoid unnecessarily } \\
\text { complex download } \\
\text { process. }\end{array}$ \\
\hline Research & $\begin{array}{l}\text { Evidence } \\
\text { speci- } \\
\text { ficity/Quality }\end{array}$ & 3.5 & $\begin{array}{l}\text { Outputs that are made } \\
\text { available appear to be } \\
\text { of good quality. }\end{array}$ & $\begin{array}{l}\text { There are constraints } \\
\text { around being able to } \\
\text { re-use data. }\end{array}$ & $\begin{array}{l}\text { Data are available, but } \\
\text { often at considerable } \\
\text { cost in terms of time or } \\
\text { fees which means others } \\
\text { cannot easily use to } \\
\text { inform their own } \\
\text { assessments. }\end{array}$ & $\begin{array}{l}\text { All research data should } \\
\text { be stored on public } \\
\text { databases to aid access. } \\
\text { Database access should } \\
\text { be user developed rather } \\
\text { than holder developed to } \\
\text { avoid unnecessarily } \\
\text { complex download } \\
\text { process. }\end{array}$ \\
\hline
\end{tabular}


Table A17. Cont.

\begin{tabular}{|c|c|c|c|c|c|c|}
\hline $\begin{array}{l}\text { Thematic } \\
\text { Area }\end{array}$ & Element & Score & Rationale/Justification & $\begin{array}{c}\text { Limitations/Gaps } \\
\text { Examples }\end{array}$ & $\begin{array}{l}\text { What This Means in } \\
\text { Practice }\end{array}$ & $\begin{array}{l}\text { Recommendations for } \\
\text { Improvement }\end{array}$ \\
\hline Research & Confidence & 3 & $\begin{array}{l}\text { Data appear to be of } \\
\text { good quality and are } \\
\text { generally specific to the } \\
\text { question/hypothesis } \\
\text { being investigated. }\end{array}$ & $\begin{array}{l}\text { Most studies are too } \\
\text { small in scale to be } \\
\text { applied beyond the } \\
\text { scale of the study. Very } \\
\text { few studies focus on } \\
\text { effects at the ecosystem } \\
\text { level. }\end{array}$ & $\begin{array}{l}\text { Confidence in the } \\
\text { individual studies is } \\
\text { good. However, } \\
\text { extrapolation to } \\
\text { ecosystem-level effects } \\
\text { is very limited. }\end{array}$ & $\begin{array}{l}\text { Research into how } \\
\text { current data can be } \\
\text { pulled together, but also } \\
\text { going forward, standard } \\
\text { data requirements set by } \\
\text { regulators to aid in } \\
\text { comparability and } \\
\text { carrying out } \\
\text { ecosystem-level } \\
\text { assessments. }\end{array}$ \\
\hline Research & $\begin{array}{l}\text { Evidence/ } \\
\text { knowledge } \\
\text { base }\end{array}$ & 2.5 & $\begin{array}{l}\text { There are certain areas } \\
\text { of research which have } \\
\text { received a of research } \\
\text { and a sound evidence } \\
\text { base. These include } \\
\text { seabirds, underwater } \\
\text { noise, and marine } \\
\text { mammals. }\end{array}$ & $\begin{array}{c}\text { Areas such as effects of } \\
\text { EMF, effects on benthos } \\
\text { and effects on fisheries } \\
\text { have received relatively } \\
\text { little research. }\end{array}$ & $\begin{array}{l}\text { Research in many areas } \\
\text { is being driving by } \\
\text { licensing issues, often } \\
\text { receptor groups such as } \\
\text { seabirds and marine } \\
\text { mammals. }\end{array}$ & $\begin{array}{l}\text { Research should be } \\
\text { ecosystem-led and } \\
\text { coordinated to avoid } \\
\text { duplication of effort. } \\
\text { Programmes of sufficient } \\
\text { size are required to } \\
\text { answer }\end{array}$ \\
\hline Assessment & $\begin{array}{l}\text { Research } \\
\quad \text { (data } \\
\text { available to } \\
\text { inform as- } \\
\text { sessments) }\end{array}$ & 2.5 & $\begin{array}{l}\text { Data appear to be of } \\
\text { good quality and are } \\
\text { generally specific to the } \\
\text { question/hypothesis } \\
\text { being investigated. }\end{array}$ & $\begin{array}{l}\text { There are constraints } \\
\text { around being able to } \\
\text { re-use data. }\end{array}$ & $\begin{array}{l}\text { Data are available, but } \\
\text { often at considerable } \\
\text { cost in terms of time or } \\
\text { fees which means others } \\
\text { cannot easily use to } \\
\text { inform their own } \\
\text { assessments. }\end{array}$ & $\begin{array}{c}\text { All research data should } \\
\text { be stored on public } \\
\text { databases to aid access. } \\
\text { Database access should } \\
\text { be user developed rather } \\
\text { than holder developed to } \\
\text { avoid unnecessarily } \\
\text { complex download } \\
\text { process. }\end{array}$ \\
\hline Assessment & $\begin{array}{l}\text { Tools } \\
\text { availability }\end{array}$ & 3 & $\begin{array}{c}\text { There are established } \\
\text { guidelines for carrying } \\
\text { out EIAs across } \\
\text { industries. }\end{array}$ & $\begin{array}{c}\text { Identifying which } \\
\text { species and impacts to } \\
\text { be assessed is } \\
\text { industry/site specific } \\
\text { and requires expert } \\
\text { judgement. }\end{array}$ & $\begin{array}{l}\text { Whilst there are } \\
\text { guidelines in place, } \\
\text { these are generic to } \\
\text { cover and cannot cover } \\
\text { all species, impacts or } \\
\text { environmental } \\
\text { conditions and therefore } \\
\text { assessments are often } \\
\text { subject to subjectivity in } \\
\text { the assessor and } \\
\text { reviewer. }\end{array}$ & $\begin{array}{l}\text { Whilst there will always } \\
\text { be a degree of } \\
\text { subjectivity, } \\
\text { Regulator-led standards } \\
\text { could reduce the } \\
\text { subjectivity. }\end{array}$ \\
\hline
\end{tabular}

\begin{tabular}{|c|c|c|c|c|c|c|}
\hline Assessment & Timeliness & $\mathrm{N} / \mathrm{A}$ & \multicolumn{4}{|c|}{$\begin{array}{l}\text { This is not considered as a separate thematic topic area as it is captured under confidence/timeliness as } \\
\text { confidence linked to timing of monitoring. }\end{array}$} \\
\hline Assessment & Confidence & 2.5 & $\begin{array}{l}\text { Data appear to be of } \\
\text { good quality and are } \\
\text { generally specific to the } \\
\text { question/hypothesis } \\
\text { being investigated. }\end{array}$ & $\begin{array}{l}\text { There is no formal } \\
\text { process of cross } \\
\text { checking or quality } \\
\text { assuring data produced } \\
\text { by developers. }\end{array}$ & $\begin{array}{l}\text { Reviewers cannot } \\
\text { review the quality } \\
\text { assurances processes } \\
\text { nor all the steps to } \\
\text { assure themselves in the } \\
\text { assessment and } \\
\text { therefore decisions are } \\
\text { based on whether the } \\
\text { approaches and } \\
\text { conclusions appear } \\
\text { reasonable. }\end{array}$ & $\begin{array}{l}\text { Regulator-led data } \\
\text { standards would reduce } \\
\text { the uncertainty in } \\
\text { confidence levels. } \\
\text { Demonstrating the data } \\
\text { collection, cleansing and } \\
\text { analysis steps in line } \\
\text { with regulator-led } \\
\text { standards would } \\
\text { increase confidence in } \\
\text { decisions. }\end{array}$ \\
\hline
\end{tabular}

Assessment Use N/A This is not considered as a separate thematic topic area as it is captured under Research which takes into
account the usability of the data.

\begin{tabular}{|c|c|c|c|c|c|c|}
\hline Monitoring & $\begin{array}{c}\text { Data } \\
\text { availability }\end{array}$ & 3.5 & $\begin{array}{l}\text { Data produced from } \\
\text { baseline surveys and } \\
\text { monitoring can be made } \\
\text { available. }\end{array}$ & $\begin{array}{l}\text { Data are not always } \\
\text { easily available and, in } \\
\text { some circumstances, } \\
\text { relies on knowledge on } \\
\text { the data existing. }\end{array}$ & $\begin{array}{l}\text { Data are available, but } \\
\text { often at considerable } \\
\text { cost in terms of time or } \\
\text { fees which means others } \\
\text { cannot easily use to } \\
\text { inform their own } \\
\text { assessments. }\end{array}$ & $\begin{array}{c}\text { All research data should } \\
\text { be stored on public } \\
\text { databases to aid access. } \\
\text { Database access should } \\
\text { be user developed rather } \\
\text { than holder developed to } \\
\text { avoid unnecessarily } \\
\text { complex download } \\
\text { process. }\end{array}$ \\
\hline
\end{tabular}


Table A17. Cont.

\begin{tabular}{|c|c|c|c|c|c|c|}
\hline $\begin{array}{c}\text { Thematic } \\
\text { Area }\end{array}$ & Element & Score & Rationale/Justification & $\begin{array}{c}\text { Limitations/Gaps } \\
\text { Examples }\end{array}$ & $\begin{array}{l}\text { What This Means in } \\
\text { Practice }\end{array}$ & $\begin{array}{l}\text { Recommendations for } \\
\text { Improvement }\end{array}$ \\
\hline Monitoring & $\begin{array}{l}\text { Confidence/ } \\
\text { timeliness }\end{array}$ & 1.5 & $\begin{array}{l}\text { Monitoring can be } \\
\text { appropriate to address } \\
\text { the issues related to the } \\
\text { EIA. }\end{array}$ & $\begin{array}{l}\text { Broader uses of such } \\
\text { data can be limited. }\end{array}$ & $\begin{array}{l}\text { Confidence in the } \\
\text { individual studies is } \\
\text { good. However, } \\
\text { extrapolation to } \\
\text { ecosystem-level effects } \\
\text { is very limited. }\end{array}$ & $\begin{array}{l}\text { Research into how } \\
\text { current data can be } \\
\text { pulled together, but also } \\
\text { going forward, standard } \\
\text { data requirements set by } \\
\text { regulators to aid in } \\
\text { comparability and } \\
\text { carrying out } \\
\text { ecosystem-level } \\
\text { assessments. }\end{array}$ \\
\hline
\end{tabular}

Some monitoring surveys are not carrying out the level of survey required to detect

Monitoring Method $1.5 \quad \begin{gathered}\text { There are international } \\ \text { standards and best } \\ \text { practice for undertaking } \\ \text { surveys and analysis. }\end{gathered}$

Some decisions are driven by cost.

change because to do so

would be costly;

therefore, often a

'compromise' is reached

to inform monitoring assessments.

Due to new technology, there is greater

Monitoring is

Monitoring Proportional $1.5 \quad$ hypothesis driven to reduce uncertainty. uncertainty regarding impacts, and therefore requires more monitoring at the inception.
Due to new technology, there is greater uncertainty regarding impacts, and therefore requires more monitoring at the inception.
Ensuring all monitoring is hypothesis driven and limitations noted at the start of the process, i.e., at survey design.

Ensuring the hypothesis is linked to the licensing condition.

Ensuring that monitoring

is proportional, i.e., new technology, or larger projects, where there is high uncertainty, may require more monitoring to understand the impacts/effects.

Use/ This is not considered as a separate thematic topic area as use/effectiveness is directly linked to hypothesis formed by
results of the associated EIA. There is no sector-wide monitoring.
results of the associated EIA. There is no sector-wide monitoring.

\begin{tabular}{|c|c|c|c|c|c|c|}
\hline Regulation & Specificity & 3 & $\begin{array}{l}\text { Specific criteria related } \\
\text { to offshore renewables } \\
\text { as to which regulations } \\
\text { projects fall under. }\end{array}$ & $\begin{array}{l}\text { The national regulations } \\
\text { were not developed } \\
\text { specifically for offshore } \\
\text { renewables. }\end{array}$ & $\begin{array}{l}\text { Often have to consult } \\
\text { multiple legislative texts } \\
\text { (MCAA, Marine EIA } \\
\text { Work Regs, Planning } \\
\text { Act) as well as previous } \\
\text { applications to ensure } \\
\text { following mandatory } \\
\text { and recommended texts, } \\
\text { as well as applying } \\
\text { consistently and any } \\
\text { variation is (still legal) } \\
\text { based on sound } \\
\text { evidence. }\end{array}$ & $\begin{array}{l}\text { None } \\
\text { recommended-the } \\
\text { regulations are updated } \\
\text { to reflect changes in } \\
\text { methods and science. } \\
\text { International treaties are } \\
\text { clear. Recommend } \\
\text { guidelines stay as } \\
\text { guidelines and not made } \\
\text { mandatory as one size } \\
\text { does not fit all. }\end{array}$ \\
\hline Regulation & Implementation & 3 & $\begin{array}{l}\text { Regulations have been } \\
\text { implemented for } \\
\text { offshore renewables } \\
\text { including offshore wind } \\
\text { and demonstration } \\
\text { projects for tidal. }\end{array}$ & $\begin{array}{l}\text { New technologies are } \\
\text { being developed which } \\
\text { have yet to be tested } \\
\text { under the regulations. }\end{array}$ & $\begin{array}{c}\text { With larger } \\
\text { developments (Round } \\
\text { 4) moving into less } \\
\text { understood waters, and } \\
\text { new technologies } \\
\text { advancing, need to } \\
\text { ensure the assessments } \\
\text { and monitoring are in } \\
\text { line with current } \\
\text { legislation but as these } \\
\text { evolve, weaknesses may } \\
\text { be identified. }\end{array}$ & $\begin{array}{l}\text { No major weaknesses } \\
\text { identified at present, } \\
\text { more highlighting the } \\
\text { need to be aware of } \\
\text { advancements which } \\
\text { have yet to be legally } \\
\text { tested in terms of } \\
\text { assessment. }\end{array}$ \\
\hline Regulation & Timeliness & \multicolumn{5}{|c|}{ This is not considered as a separate thematic topic area as it is captured under Implementation. } \\
\hline Regulation & $\begin{array}{c}\text { Monitoring/ } \\
\text { Review }\end{array}$ & 1 & $\begin{array}{l}\text { It is an obligation for } \\
\text { any changes to be } \\
\text { picked up and } \\
\text { implemented by the } \\
\text { relevant departments } \\
\text { including advisory } \\
\text { bodies but no } \\
\text { statutory/regular } \\
\text { review in place. }\end{array}$ & $\begin{array}{c}\text { Frequency is not } \\
\text { defined but at the } \\
\text { discretion of the } \\
\text { competent authorities } \\
\text { and usually occur due } \\
\text { to major legislative or } \\
\text { policy landscape } \\
\text { changes. }\end{array}$ & $\begin{array}{l}\text { Due to the time and cost } \\
\text { of updating regulations, } \\
\text { this tends to be carried } \\
\text { out when there is a } \\
\text { major shift in } \\
\text { understanding. Smaller } \\
\text { discrepancies may be } \\
\text { put 'on hold'. }\end{array}$ & $\begin{array}{l}\text { None } \\
\text { recommended-the } \\
\text { regulations are updated } \\
\text { to reflect changes in } \\
\text { methods and science. } \\
\text { International treaties are } \\
\text { clear. Recommend } \\
\text { guidelines stay as } \\
\text { guidelines and not made } \\
\text { mandatory as one size } \\
\text { does not fit all. New } \\
\text { provisions need to be } \\
\text { effectively implemented } \\
\text { and tested. }\end{array}$ \\
\hline
\end{tabular}


Table A17. Cont.

\begin{tabular}{|c|c|c|c|c|c|c|}
\hline $\begin{array}{l}\text { Thematic } \\
\text { Area }\end{array}$ & Element & Score & Rationale/Justification & $\begin{array}{c}\text { Limitations/Gaps } \\
\text { Examples }\end{array}$ & $\begin{array}{l}\text { What This Means in } \\
\text { Practice }\end{array}$ & $\begin{array}{l}\text { Recommendations for } \\
\text { Improvement }\end{array}$ \\
\hline Policy & $\begin{array}{l}\text { Evidence } \\
\text { base/data } \\
\text { availability } \\
\text { (to inform } \\
\text { policy) }\end{array}$ & 3 & $\begin{array}{l}\text { The UK policy has been } \\
\text { drawn together based } \\
\text { on a number of national } \\
\text { and international } \\
\text { drivers. }\end{array}$ & $\begin{array}{l}\text { There are some cases } \\
\text { where these are not } \\
\text { interpreted } \\
\text { appropriately and are } \\
\text { designed for legal } \\
\text { protection as opposed } \\
\text { to sustainable } \\
\text { development. }\end{array}$ & $\begin{array}{l}\text { Advancements can take } \\
\text { time to come online as } \\
\text { impact assessments } \\
\text { must be undertaken, as } \\
\text { well as challenging the } \\
\text { legality of changes } \\
\text { (does it change our } \\
\text { position legally) and the } \\
\text { robustness of evidence } \\
\text { (does the change make a } \\
\text { marked step forward in } \\
\text { terms of evidence } \\
\text { confidence?). }\end{array}$ & $\begin{array}{l}\text { Due to new technologies } \\
\text { (e.g., floating wind, } \\
\text { lagoons), policies may } \\
\text { require updating for the } \\
\text { 'UK view' }\end{array}$ \\
\hline Policy & $\begin{array}{l}\text { Evidence/data } \\
\text { quality }\end{array}$ & & \multicolumn{4}{|c|}{ This is not considered as a separate thematic topic area as it is captured under Research. } \\
\hline Policy & $\begin{array}{l}\text { Stakeholder/ } \\
\text { public un- } \\
\text { derstanding }\end{array}$ & 0.5 & $\begin{array}{l}\text { There are policies } \\
\text { regarding } \\
\text { decarbonisation and } \\
\text { renewable energy } \\
\text { sources. }\end{array}$ & $\begin{array}{l}\text { There is little public } \\
\text { understanding } \\
\text { regarding the } \\
\text { complexities that are } \\
\text { required to be assessed } \\
\text { and balanced by the } \\
\text { regulators and decision } \\
\text { makers. }\end{array}$ & $\begin{array}{l}\text { The public tend to be in } \\
\text { favour or against } \\
\text { renewable energy, due } \\
\text { to the NIMBY attitude } \\
\text { [39], but they may not } \\
\text { be aware of all of the } \\
\text { UKs international } \\
\text { obligations to meet } \\
\text { targets such as \% of } \\
\text { energy from renewable } \\
\text { sources. }\end{array}$ & $\begin{array}{l}\text { Education of the public } \\
\text { on marine management, } \\
\text { as a whole, as there is no } \\
\text { one approach to } \\
\text { management, nor one } \\
\text { solution. }\end{array}$ \\
\hline Policy & $\begin{array}{l}\text { Resource } \\
\text { allocation }\end{array}$ & 1 & $\begin{array}{l}\text { UK government has } \\
\text { recently created an } \\
\text { Offshore Wind team to } \\
\text { ensure this joined up } \\
\text { approach is established } \\
\text { and maintained to } \\
\text { deliver the } \\
\text { decarbonisation targets. }\end{array}$ & $\begin{array}{l}\text { There is recognition that } \\
\text { there are steps to } \\
\text { improve this to meet the } \\
\text { ambitions. }\end{array}$ & $\begin{array}{l}\text { This team looks across } \\
\text { the board at the } \\
\text { potential for meeting } \\
\text { UK targets but also } \\
\text { conflicts with other } \\
\text { marine users such as } \\
\text { MPAs. This is a } \\
\text { relatively new team } \\
\text { hence the low score. }\end{array}$ & $\begin{array}{c}\text { To ensure } \\
\text { cross-government } \\
\text { collaboration and } \\
\text { communication } \\
\text { regarding offshore } \\
\text { renewables to ensure no } \\
\text { duplication of effort } \\
\text { (wasting resource) but } \\
\text { also highlight and } \\
\text { prioritise gaps, to make } \\
\text { best use of resources. }\end{array}$ \\
\hline Policy & Confidence & 1.5 & $\begin{array}{l}\text { UK policy has been } \\
\text { drawn together based } \\
\text { on a number of national } \\
\text { and international } \\
\text { drivers }\end{array}$ & $\begin{array}{l}\text { Development is based } \\
\text { on aspirational targets } \\
\text { set at international fora, } \\
\text { but this may not be } \\
\text { achievable either due to } \\
\text { technological status, } \\
\text { regulatory burden, or } \\
\text { uncertainty in the } \\
\text { science. }\end{array}$ & $\begin{array}{l}\text { Development is based } \\
\text { on aspirational targets } \\
\text { set at international fora, } \\
\text { but this may not be } \\
\text { achievable either due to } \\
\text { technological status, } \\
\text { regulatory burden, or } \\
\text { uncertainty in the } \\
\text { science. }\end{array}$ & $\begin{array}{l}\text { To undertake an analysis } \\
\text { of whether the UK could } \\
\text { achieve the aspirational } \\
\text { targets and, if not, why } \\
\text { not to focus priorities, } \\
\text { etc. }\end{array}$ \\
\hline Policy & Proportional & 2 & $\begin{array}{l}\text { The policy regarding } \\
\text { offshore renewables has } \\
\text { been developed and is } \\
\text { increasing, due to a } \\
\text { combination of factors: } \\
\text { lower availability of oil } \\
\text { and gas, which is } \\
\text { increasing prices; } \\
\text { increasing need for } \\
\text { energy efficiency and to } \\
\text { reduce greenhouse gas } \\
\text { emissions to lower the } \\
\text { rate and impacts of } \\
\text { climate change. }\end{array}$ & $\begin{array}{l}\text { Lack of current resource } \\
\text { and strategic overview, } \\
\text { low public awareness of } \\
\text { the intricacies behind } \\
\text { the policies and } \\
\text { decision making. It is } \\
\text { acknowledged that } \\
\text { there is a lag between } \\
\text { the policies being } \\
\text { implemented and the } \\
\text { targets being achieved }\end{array}$ & $\begin{array}{l}\text { The public are not } \\
\text { aware of the intricacies } \\
\text { of ensuring the UK } \\
\text { meet our targets and } \\
\text { therefore can object to } \\
\text { developments without } \\
\text { the bigger picture. } \\
\text { There can be conflicts } \\
\text { between targets (MPAs } \\
\text { and offshore } \\
\text { renewables). }\end{array}$ & $\begin{array}{l}\text { Educate the public. } \\
\text { Allow the Offshore Wind } \\
\text { Enabling Team to look } \\
\text { across the broader } \\
\text { marine environment to } \\
\text { consider synergies and } \\
\text { conflicts. To undertake } \\
\text { an analysis of whether } \\
\text { the UK could achieve the } \\
\text { aspirational targets and, } \\
\text { if not, why not to focus } \\
\text { priorities, etc. }\end{array}$ \\
\hline
\end{tabular}

\section{References}

1. Cabral, H.; Marques, J.C.; Guilhermino, L.; de Jonge, V.; Elliott, M. Coastal systems under change: Tuning assessment and management tools. Estuar. Coast. Shelf Sci. 2016, 167, 1-3. [CrossRef]

2. Lonsdale, J.; Birchenough, A. Dredge Material Disposal Sites and Marine Protected Areas around the English Coast: Desk Review-Part 2; Final Report, Report for Natural England, Cefas Contract Report C6230; Cefas: Lowestoft, UK, 2014.

3. Knights, A.M.; Koss, R.S.; Robinson, L.A. Identifying common pressure pathways from a complex network of human activities to support ecosystem-based management. Ecol. Appl. 2013, 23, 755-765. [CrossRef] [PubMed] 
4. Goodsir, F.; Bloomfield, H.J.; Judd, A.D.; Kral, F.; Robinson, L.A.; Knights, A.M. A spatially resolved pressure-based approach to evaluate combined effects of human activities and management in marine ecosystems. ICES J. Mar. Sci 2015, 72, 2245-2256. [CrossRef]

5. Austen, M.C.; Crowe, T.P.; Elliott, M.; Paterson, D.M.; Peck, M.A.; Piraino, S. VECTORS of change in the marine environment: Ecosystem and economic impacts and management implications. Estuar. Coast. Shelf Sci. 2018, 201, 1-6. [CrossRef]

6. Rosenberg, A.A.; McLeod, K.L. Implementing ecosystem-based approaches to management for the conservation of ecosystem services. Mar. Ecol. Prog. Ser. 2005, 300, 270-274. [CrossRef]

7. Maxwell, S.M.; Hazen, E.L.; Lewison, R.L.; Dunn, D.C.; Bailey, H.; Bograd, S.J.; Briscoe, D.K.; Fossette, S.; Hobday, A.J.; Bennett, M.; et al. Dynamic ocean management: Defining and conceptualizing real-time management of the ocean. Mar. Policy 2015, 58, 42-50. [CrossRef]

8. Elliott, M.; Borja, A.; McQuatters-Gollop, A.; Mazik, K.; Birchenough, S.N.R.; Andersen, J.H.; Painting, S.; Peck, M. Force majeure: Will climate change affect our ability to attain good environmental status for marine biodiversity? Mar. Pollut. 2015, 95, 7-27. [CrossRef] [PubMed]

9. Galler, C.; Albert, C.; von Haaren, C. From regional environmental planning to implementation: Paths and challenges of integrating ecosystem services. Ecosystem 2016, 18, 18-129. [CrossRef]

10. Aubry, A.; Elliott, M. The use of environmental integrative indicators to assess seabed disturbance in estuaries and coasts: Application to the Humber Estuary, UK. Mar. Pollut. 2006, 53, 175-185. [CrossRef]

11. Scarff, G.; Fitzsimmons, C.; Gray, T. The new mode of marine planning in the UK: Aspirations and challenges. Mar. Policy 2015, 51, 96-102. [CrossRef]

12. Markus, T. Challenges and foundations of sustainable ocean governance. In Handbook on Marine Environment Protection; Springer: Cham, Switzerland, 2018; pp. 545-562.

13. McDonald, K.S.; Hobday, A.J.; Thompson, P.A.; Lenton, A.; Stephenson, R.L.; Mapstone, B.D.; Dutra, L.X.; Bessey, C.; Boschetti, F.; Cvitanovic, C.; et al. Proactive, reactive, and inactive pathways for scientists in a changing world. Earths Future 2019, 7, 60-73. [CrossRef]

14. McKinley, E.; Ballinger, R.C. Welsh legislation in a new era: A stakeholder perspective for coastal management. Mar. Policy 2018, 97, 253-261. [CrossRef]

15. Shyam, S.S.; Shridhar, N.; Fernandez, R. Climate change and need for proactive policy initiatives in Indian marine fisheries sector. Clim. Change 2017, 3, 20-37.

16. HM Government. UK Marine Policy Statement; The Stationary Office: London, UK, 2011.

17. Carpenter, S.R.; Mooney, H.A.; Agard, J.; Capistrano, D.; DeFries, R.S.; Díaz, S.; Dietz, T.; Duraiappah, A.K.; Oteng-Yeboah, A.; Pereira, H.M.; et al. Science for managing ecosystem services: Beyond the millennium ecosystem assessment. Proc. Natl. Acad. Sci. USA 2009, 106, 1305-1312. [CrossRef]

18. Gill, A.B.; Birchenough, S.N.; Jones, A.R.; Judd, A.; Jude, S.; Payo-Payo, A.; Wilson, B. Environmental implications of offshore energy. In Offshore Energy and Marine Spatial Planning; Routledge: Oxfordshire, UK, 2018; pp. 132-168.

19. Claudet, J.; Bopp, L.; Cheung, W.W.L.; Devillers, R.; Escobar-Briones, E.; Haugan, P.; Heymans, J.J.; Masson-Delmotte, V.; Matz-Lück, N.; Miloslavich, P.; et al. A Roadmap for Using the UN Decade of ocean science for sustainable development in support of science, policy and action. ONE Earth 2020, 2, 34-42. [CrossRef]

20. Willsteed, E.A.; Jude, S.; Gill, A.B.; Birchenough, S.N. Obligations and aspirations: A critical evaluation of offshore wind farm cumulative impact assessments. Renew. Sustain. Energy Rev. 2018, 82, 2332-2345. [CrossRef]

21. Ware, S.; Langman, R.; Lowe, S.; Weiss, L.; Walker, R.; Mazik, K. The Applicability of Environmental Indicators of Change to the Management of marine Aggregate Extraction; CEFAS: London, UK, 2010.

22. Bolam, S.G.; Rees, H.L.; Somerfield, P.; Smith, R.; Clarke, K.R.; Warwick, R.M.; Atkins, M.; Garnacho, E. Ecological consequences of dredged material disposal in the marine environment: A holistic assessment of activities around England and Wales coastline. Mar. Pollut. 2006, 52, 415-426. [CrossRef]

23. JNCC. UK Marine Protected Area Network Statistics. 2020. Available online: https://jncc.gov.uk/our-work/uk-marineprotected-area-network-statistics / (accessed on 12 December 2021).

24. JNCC; Natural England. Levels of Evidence Required for the Identification, Designation, and Management of Marine Conservation Zones; Natural England: York, UK; The Joint Nature Conservation Committee: Peterborough, UK, 2011; p. 11. Available online: http:/ / data.jncc.gov.uk/data/c812bf90-1e37-4623-ab6a-e97f471a2492/MCZ-LevelsOfEvidence-2011-JNCC-NE.pdf (accessed on 12 December 2021)

25. JNCC; Natural England. MCZ Levels of Evidence. Advice on When Data Supports a Feature/Site for Designation from a Scientific, Evidence-Based Perspective. 2016; 25p. Available online: http:/ / data.jncc.gov.uk/data/c812bf90-1e37-4623-ab6a-e97f4 71a2492/MCZ-levels-of-evidence-Addendum-2016.pdf (accessed on 12 December 2021).

26. Walker, P.; Mason, R.; Carrington, D. Theresa May commits to net zero UK carbon emissions by 2050. Guardian 2019, 11, 19.

27. The Crown Estate. Offshore Wind Operational Report. January-December 2018; The Crown Estate: London, UK, $2020 ;$ p. 24.

28. James, R.; Martins, E. Future Potential for Offshore Wind in Wales. The Carbon Trust Prepared for the Welsh Government. December 2018. Available online: https://gov.wales/sites/default/files/publications/2019-07/future-potential-for-offshorewind.pdf (accessed on 12 December 2021). 
29. MMO. Review of Post-Consent Offshore Wind Farm Monitoring Data Associated with Licence Conditions. A Report Produced for the Marine Management Organisation; Marine Management Organization: Newcastle, UK, 2014; 194p, ISBN 978-1-909452-24-4. Available online: https://assets.publishing.service.gov.uk/government/uploads/system/uploads/attachment_data/file/317787/1031. pdf (accessed on 12 December 2021).

30. Birchenough, S.N.; Degraer, S. Science in support of ecologically sound decommissioning strategies for offshore man-made structures: Taking stock of current knowledge and considering future challenges. ICES J. Mar. Sci. 2020, 77, 1075-1078. [CrossRef]

31. Goodsir, F.; Lonsdale, J.A.; Mitchell, P.J.; Suehring, R.; Farcas, A.; Whomersley, P.; Brant, J.L.; Clarke, C.; Kirby, M.F.; Skelhorn, M.; et al. A standardized approach to the environmental risk assessment of potentially polluting wrecks. Mar. Pollut. Bull. 2019, 142, 290-302. [CrossRef]

32. Skov, H.; Heinänen, S.; Norman, T.; Ward, R.; Méndez, S. ORJIP Bird Avoidance Behaviour and Collision Impact Monitoring at Offshore Wind Farms; The Carbon Trust: London, UK, 2018.

33. Graham, I.M.; Pirotta, E.; Merchant, N.D.; Farcas, A.; Barton, T.R.; Cheney, B.; Hastie, G.D.; Thompson, P.M. Responses of bottlenose dolphins and harbor porpoises to impact and vibration piling noise during harbor construction. Ecosphere 2017, 8 , e01793. [CrossRef]

34. Blair, H.B.; Merchant, N.D.; Friedlaender, A.S.; Wiley, D.N.; Parks, S.E. Evidence for ship noise impacts on humpback whale foraging behaviour. Biol. Lett. 2016, 12, 20160005. [CrossRef] [PubMed]

35. Jones, E.L.; Hastie, G.D.; Smout, S.; Onoufriou, J.; Merchant, N.D.; Brookes, K.L.; Thompson, D. Seals and shipping: Quantifying population risk and individual exposure to vessel noise. J. Appl. Ecol. 2017, 54, 1930-1940. [CrossRef]

36. Hutchison, Z.L.; Gill, A.B.; Sigray, P.; He, H.; King, J.W. Anthropogenic electromagnetic fields (EMF) influence the behaviour of bottom-dwelling marine species. Sci. Rep. 2020, 10, 4219. [CrossRef] [PubMed]

37. Dannheim, J.; Bergström, L.; Birchenough, S.N.; Brzana, R.; Boon, A.R.; Coolen, J.W.; Dauvin, J.C.; De Mesel, I.; Derweduwen, J.; Gill, A.B.; et al. Benthic effects of offshore renewables: Identification of knowledge gaps and urgently needed research. ICES J. Mar. Sci. 2019, 77, 1092-1108. [CrossRef]

38. Lonsdale, J.; Weston, K.; Blake, S.; Edwards, R.; Elliott, M. The amended European environmental impact assessment directive: UK marine experience and recommendations. Ocean. Coast. Manag. 2017, 148, 131-142. [CrossRef]

39. Wolsink, M. Wind power and the NIMBY-myth: Institutional capacity and the limited significance of public support. Renew. Energy 2000, 21, 49-64. [CrossRef] 